\title{
Role of Ventral Subiculum in Context-Induced Relapse to Alcohol Seeking after Punishment-Imposed Abstinence
}

\author{
Nathan J. Marchant, ${ }^{1,4}$ Erin J. Campbell, ${ }^{7}$ Leslie R. Whitaker, ${ }^{1}$ Brandon K. Harvey, ${ }^{2}$ CKonstantin Kaganovsky, ${ }^{1}$ \\ Sweta Adhikary, ${ }^{1}$ Bruce T. Hope, ${ }^{1}$ Robert C. Heins, ${ }^{1}$ Thomas E. Prisinzano, ${ }^{5}$ Eyal Vardy, ${ }^{6}$ Antonello Bonci, ${ }^{3}$ \\ 미 Jennifer M. Bossert, ${ }^{1}$ and $\odot$ Yavin Shaham ${ }^{1}$ \\ ${ }^{1}$ Behavioral Neuroscience Branch, ${ }^{2}$ Optogenetics and Transgenic Technology Core, and ${ }^{3}$ Cellular Neurobiology Research Branch, National Institute on Drug \\ Abuse-IRP, National Institutes of Health, Baltimore, Maryland 21224, ${ }^{4}$ Florey Institute of Neuroscience and Mental Health, University of Melbourne, \\ Melbourne, 2337 Australia, ${ }^{5}$ Department of Medicinal Chemistry, School of Pharmacy, University of Kansas, Lawrence, Kansas 66045, ${ }^{6}$ Merck \\ Pharmaceuticals, Kenilworth, New Jersey 07033, and 7Neurobiology of Addiction Laboratory, School of Biomedical Sciences and Pharmacy, University of \\ Newcastle, the Priority Research Centre for Translational Neuroscience and Mental Health and the Hunter Medical Research Institute, Newcastle, 2308, \\ Australia
}

In many human alcoholics, abstinence is self-imposed because of the negative consequences of excessive alcohol use, and relapse is often triggered by exposure to environmental contexts associated with prior alcohol drinking. We recently developed a rat model of this human condition in which we train alcohol-preferring $\mathrm{P}$ rats to self-administer alcohol in one context (A), punish the alcohol-reinforced responding in a different context (B), and then test for relapse to alcohol seeking in Contexts A and B without alcohol or shock. Here, we studied the role of projections to nucleus accumbens $(\mathrm{NAc}$ ) shell from ventral subiculum (vSub), basolateral amygdala, paraventricular thalamus, and ventral medial prefrontal cortex in context-induced relapse after punishment-imposed abstinence. First, we measured double-labeling of the neuronal activity marker Fos with the retrograde tracer cholera toxin subunit B (injected in NAc shell) and demonstrated that context-induced relapse is associated with selective activation of the $\mathrm{vSub} \rightarrow \mathrm{NAc}$ shell projection. Next, we reversibly inactivated the vSub with GABA receptor agonists (muscimol + baclofen) before the context-induced relapse tests and provided evidence for a causal role of vSub in this relapse. Finally, we used a dual-virus approach to restrict expression of the inhibitory $\kappa$ opioid-receptor based DREADD (KORD) in vSub $\rightarrow$ NAc shell projection neurons. We found that systemic injections of the KORD agonist salvinorin B, which selectively inhibits KORD-expressing neurons, decreased context-induced relapse to alcohol seeking. Our results demonstrate a critical role of vSub in context-induced relapse after punishment-imposed abstinence and further suggest a role of the vSub $\rightarrow \mathrm{NAc}$ projection in this relapse.

Key words: alcohol; chemogenetics; nucleus accumbens; punishment; relapse; ventral subiculum

\section{Significance Statement}

In many human alcoholics, abstinence is self-imposed because of the negative consequences of excessive use, and relapse is often triggered by exposure to environmental contexts associated with prior alcohol use. Until recently, an animal model of this human condition did not exist. We developed a rat model of this human condition in which we train alcohol-preferring P rats to selfadminister alcohol in one context (A), punish the alcohol-reinforced responding in a different context (B), and test for relapse to alcohol seeking in Contexts A and B. Here, we used neuroanatomical, neuropharmacological, and chemogenetic methods to demonstrate a role of ventral subiculum and potentially its projections to nucleus accumbens in context-induced relapse after punishment-imposed abstinence.

\section{Introduction}

In abstinent alcoholics, exposure to environments previously associated with alcohol use often causes relapse (Wikler, 1973; Col- lins and Brandon, 2002). We and others have modeled this phenomenon in rats using the ABA renewal model (Bouton and Bolles, 1979). In this model, rats are first trained to selfadminister a drug in one context (A). Next, they are given oper- 
ant extinction training in a different context (B), leading to cessation of drug seeking. During testing, renewal (or contextinduced reinstatement) of drug seeking is observed when the rat returns to the original training Context A (Crombag and Shaham, 2002; Hamlin et al., 2007). Over the last decade, studies using this model have led to the identification of mechanisms of context-induced reinstatement of drug seeking after extinction (Fuchs et al., 2008a; McNally, 2014; Marchant et al., 2015).

However, a limitation of extinction-based models is the use of experimenter-imposed operant extinction to achieve abstinence (Epstein and Preston, 2003). This manipulation is different from human abstinence, which is typically self-imposed because of the adverse consequences of drug use (Klingemann, 1991; Blume et al., 2006). We recently developed a variation of the ABA renewal model (Marchant et al., 2013; see also Bouton and Schepers, 2015), where alcohol intake is suppressed by adverse consequences in Context B (punishment). We observed contextinduced relapse to alcohol seeking when rats were tested in Context A after punishment-imposed abstinence in Context B (Marchant et al., 2013).

The nucleus accumbens (NAc) shell plays a critical role in context-induced reinstatement of drug seeking after extinction (Bossert et al., 2013). We recently found that blockade of NAc shell dopamine D1 receptors (D1R), which decreases striatal neuronal activity (Girault et al., 2007), blocks context-induced relapse to alcohol seeking after punishment (Marchant and Kaganovsky, 2015). In NAc shell, neuronal activity is dependent on synergistic activation of D1R and glutamate receptors (O'Donnell, 2003). Inhibition of glutamate transmission in NAc shell decreases context-induced reinstatement of heroin and cocaine seeking after extinction (Bossert et al., 2006; Xie et al., 2012); however, local injections of glutamate receptor antagonists also cause reinstatement of alcoholic beer seeking after extinction (Millan and McNally, 2011). Additionally, neuroanatomical disconnection of the ventral subiculum (vSub) $\rightarrow \mathrm{NAc}$ shell or vSub inactivation decreases context-induced reinstatement of heroin seeking (Bossert and Stern, 2014; Bossert et al., 2015). There is also evidence that the two other glutamatergic projections from the basolateral amygdala (BLA) and paraventricular thalamus (PVT) to NAc shell (Voorn et al., 2004) contribute to contextinduced reinstatement after extinction (Fuchs et al., 2005; Hamlin et al., 2009; Marinelli et al., 2010).

Here we studied the role of the projections to NAc shell in context-induced relapse to alcohol seeking after punishmentimposed abstinence. We first combined retrograde tracing, via cholera toxin subunit $\mathrm{B}(\mathrm{CTb})$ injections into NAc shell, with detection of the neuronal activity marker Fos (Morgan and Curran, 1991) to determine relapse-associated activity in vSub, PVT, BLA, and ventral medial prefrontal cortex (vmPFC) neurons projecting to NAc shell. We found that context-induced relapse was associated with selective activation of the vSub $\rightarrow$ NAc shell projection. Next, we determined the causal role of vSub in context-induced relapse by showing that reversible inactivation of vSub by GABAa + GABAb receptor agonists (muscimol+baclofen) (McFarland and Kalivas, 2001) decreased this form of relapse. Finally, we used DREADD technology (Armbruster et al., 2007) to selectively inhibit the vSub $\rightarrow$ NAc shell projection during the relapse tests. We used a dual-virus approach

The authors declare no competing financial interests.

Correspondence should be addressed to either Dr. Nathan J. Marchant or Dr. Yavin Shaham, Behavioral Neuroscience Branch, National Institute on Drug Abuse, IRP, 251 Bayview Blvd, Suite 200, Baltimore, MD 21224; E-mail: nathan.marchant@nih.gov or yavin.shaham@nih.gov.

DOI:10.1523/JNEUROSCI.4299-15.2016

Copyright $\odot 2016$ the authors $\quad 0270-6474 / 16 / 363282-14 \$ 15.00 / 0$
(Nair et al., 2013; Boender et al., 2014; Marchant et al., 2016), by injecting AAV5-Cre into NAc shell; and in the same rat, we injected cre-inducible AAV encoding $\kappa$-opioid receptor-based DREADD (KORD) (Vardy et al., 2015) into vSub to selectively express KORD in $\mathrm{vSub} \rightarrow \mathrm{NAc}$ shell projection neurons. We found that systemic injection of the designer drug salvinorin B (SalB), which inhibits neuronal activity of KORD-expressing cells (Vardy et al., 2015; Marchant et al., 2016), decreased context-induced relapse after punishment-imposed abstinence in rats expressing KORD in vSub.

\section{Materials and Methods}

\section{Subjects and apparatus}

We received male alcohol-preferring P rats $(\sim 30$-d-old, total $n=115)$ from Indiana University Medical Centre and housed them singly under a reverse $12 \mathrm{~h}$ light/dark cycle (lights off 0800) with food and water available ad libitum. We performed all experiments in accordance to the Guide for the Care and Use of Laboratory Animals (Ed 8), and all protocols were approved by the Animal Care and Use Committee. We excluded a total of 24 rats due to lost head cap $(n=8)$, sickness or weight loss in excess of $30 \mathrm{~g}$ after intracranial injections $(n=1)$, misplaced cannula $(n=2)$, complications during surgery $(n=7)$, or low $\operatorname{KORD}(n=3)$ or hM3D ( $n=3$ expression). We used standard operant chambers (Med Associates) enclosed in a ventilated sound-attenuating cubicle illuminated by a house light for alcohol self-administration. Each chamber was equipped with one retractable lever (designated as "active") and one nonretractable lever (designated as "inactive"). The grid floors were connected to shockers. Active lever presses resulted in the delivery of $20 \%$ ethanol ( $0.1 \mathrm{ml} /$ delivery) into the receptacle via a 12-gauge blunt needle connected to a $60 \mathrm{ml}$ syringe controlled by a Razel pump. We manipulated Contexts A and B as previously described (Marchant et al., 2013): grid width (narrow/wide), illumination level (white/red house light), background noise (fan on/off), and background cues (food container present/absent within the operant chamber, cabinet doors closed/open).

\section{Behavioral procedure (four phases)}

Phase 1: Home-cage alcohol intake. We used an intermittent access (3-4 times/week) alcohol procedure (Wise, 1973; Simms et al., 2008) in which rats received $12 \times 24 \mathrm{~h}$ sessions of access to one bottle of $20 \%$ alcohol and one water bottle. We prepared alcohol solutions in tap water from $100 \%$ $(\mathrm{v} / \mathrm{v})$ ethanol in standard rat water bottles. Daily sessions began at 0900 . After $24 \mathrm{~h}$, we replaced the alcohol bottle with a second water bottle for the subsequent $24-48 \mathrm{~h}$ alcohol-free days. The following day, the second water bottle was replaced with the $20 \%$ alcohol bottle, and the location of the alcohol bottle was alternated from the previous session. Total alcohol consumption in grams was calculated for each session, using the weight difference between the beginning and end of the session, minus $2 \mathrm{~g}$ for spillage, multiplied by 0.97 (density of $20 \%$ ethanol).

Phase 2: Operant self-administration: Context A. We gave all rats two $2 \mathrm{~h}$ magazine-training sessions where $0.1 \mathrm{ml}$ of alcohol was delivered noncontingently every $5 \mathrm{~min}$ and paired with a $2 \mathrm{~s}$ tone-light cue. Next, we trained rats for six $2 \mathrm{~h}$ self-administration sessions under a fixed-ratio 1 (FR-1) schedule of reinforcement where an active lever press resulted in the delivery of $0.1 \mathrm{ml}$ of $20 \%$ alcohol paired with a $2 \mathrm{~s}$ tone-light cue. This was followed by a $20 \mathrm{~s}$ timeout period where lever presses were recorded but not reinforced. The initiation of each session was signaled by the illumination of the house light and the insertion of the active lever into the chamber. Inactive lever presses had no programmed consequences. Following FR-1 $20 \mathrm{~s}$ timeout training, we trained rats on a variableinterval $30 \mathrm{~s}$ (VI-30) schedule of reinforcement for six $2 \mathrm{~h}$ sessions. During the VI-30 sessions, alcohol delivery was available after an active lever press at pseudo-random intervals (1-59 s) after the preceding alcohol delivery.

Phase 3: Punishment: Context B. We trained rats, during $2 \mathrm{~h}$ sessions, to self-administer alcohol in an alternate context (Context B) under the same VI-30 schedule of reinforcement mentioned above. Active lever presses resulted in the delivery of $0.1 \mathrm{ml}$ of $20 \%$ alcohol paired with the $2 \mathrm{~s}$ tone-light cue. Only $50 \%$ of the reinforced active lever presses resulted in a $0.5 \mathrm{~s}$ footshock $(0.1-0.7 \mathrm{~mA})$. Punished active lever presses resulted in 
footshock, $2 \mathrm{~s}$ tone-light, and alcohol delivery. Inactive lever presses had no reinforced consequences. All rats were punished in Context B for up to $7 \mathrm{~d}$, and footshock intensity was increased by $0.1 \mathrm{~mA}$ per session, starting at $0.1 \mathrm{~mA}$. For the $\mathrm{CTb}+$ Fos experiment, we increased the shock intensity to $0.7 \mathrm{~mA}$ for all rats. For the vSub inactivation and retroDREADD experiments, we increased the shock intensity to $0.5 \mathrm{~mA}$ for all rats and then gave the rats additional punishment sessions at $0.5 \mathrm{~mA}$ or $0.6 \mathrm{~mA}$. We then tested the rats after punishment in Context B.

Phase 4: Context-induced relapse (renewal) test. We tested rats for alcohol seeking (active lever presses under extinction conditions) in $90 \mathrm{~min}$ (Experiments 1,2) or 30 min (Experiments 3, 4) sessions in either Contexts A or B (Experiment 1) or in both Contexts A and B (Experiments 2-4). The session duration was only $30 \mathrm{~min}$ in Experiments 3 and 4 because of the short half-life of SalB (Vardy et al., 2015). The order of testing in the two contexts was counterbalanced. During the tests, an active lever press, under a VI-30 schedule of reinforcement, resulted in the delivery of the $2 \mathrm{~s}$ tone-light cue and the activation of the infusion pump; no alcohol or footshock was delivered.

\section{Surgery}

We performed all surgeries after the home-cage alcohol phase of the behavioral procedures. We anesthetized rats with $100 \mathrm{mg} / \mathrm{kg}$ ketamine + $10 \mathrm{mg} / \mathrm{kg}$ xylazine (i.p.) or isoflurane (5\% induction; $2 \%-3 \%$ maintenance) before placing them in the stereotactic frame (Kopf Instruments). We injected the rats with buprenorphine $(0.1 \mathrm{mg} / \mathrm{kg}$, s.c. $)$ or ketoprofen $(2.5 \mathrm{mg} / \mathrm{kg}$, s.c., Butler Schein) after surgery and the following day (ketoprofen) to relieve pain and decrease inflammation, and gave them 3-5 $\mathrm{d}$ to recover after surgery before starting the self-administration sessions.

CTb into NAc shell. We unilaterally injected $40 \mathrm{nl}$ of $1 \%$ CTb (List Biological Laboratories) into the NAc shell over $4 \mathrm{~min}$ with the needle left in place for an additional $2 \mathrm{~min}$. We gave the injections into either the left or right hemisphere (counterbalanced) using a $1.0 \mu \mathrm{l}, 32$ gauge "Neuros" syringe (Hamilton) attached to UltraMicroPump (UMP3) with SYSMicro4 Controller (World Precision Instruments). The coordinates for NAc shell were as follows: anteroposterior 1.6 , mediolateral $\pm 2.3\left(10^{\circ}\right.$ angle), dorsoventral $-7.5 \mathrm{~mm}$ from bregma and were based on previous studies (Bossert et al., 2007).

Intracranial cannula surgery ( $\nu S u b)$. We implanted bilateral guide cannulas (23-gauge, Plastics One) $1 \mathrm{~mm}$ above the vSub. The coordinates for the vSub were as follows: anteroposterior -6.0 , mediolateral $5.3\left(4^{\circ}\right.$ angle), dorsoventral $-7.8 \mathrm{~mm}$ from bregma (Bossert and Stern, 2014; Bossert et al., 2015). We anchored the cannulas to the skull with jeweler's screws and dental cement.

Viral injections. We bilaterally injected AAV5.CMV.III.GFP-Cre. WPRE.SV40 (UPenn Vector Core lot \#V4503MI-R, titer: $9.9 \times 10^{12}$ $\mathrm{gc} / \mathrm{ml}$ or V4807MI-3CS, titer: $\left.4.9 \times 10^{12} \mathrm{gc} / \mathrm{ml}\right)$ into NAc shell: anteroposterior 1.6, mediolateral $2.3\left(10^{\circ}\right.$ angle $)$, dorsoventral $-7.5 \mathrm{~mm}$ from bregma. We injected $0.75 \mu$ l over $3 \mathrm{~min}$ and left the needle in place for $2 \mathrm{~min}$. During the same surgery, we bilaterally injected either AAV1.Syn1.dF.HA.KORD.IRES.mCitrine (NIDA Optogenetics and Transgenic Core lot \#AAV-2015-03-31-A, titer: $3.0 \times 10^{12} \mathrm{gc} / \mathrm{ml}$ ) or AAV5.hSyn.DIO.rM3D(GS)-mCherry (UNC Vector Core lot \#AV4659c, titer: $6.4 \times 10^{12} \mathrm{gc} / \mathrm{ml}$ or AV4659b, titer $\left.4.9 \times 10^{12} \mathrm{gc} / \mathrm{ml}\right)$ into vSub: anteroposterior -6.0 , mediolateral 5.3 ( $4^{\circ}$ angle), dorsoventral $-8.8 \mathrm{~mm}$ from bregma. We injected $1.0 \mu \mathrm{l}$ over $4 \mathrm{~min}$ and left the needle in place for $1 \mathrm{~min}$. Injections were made using $10 \mu \mathrm{l}$ Nanofil syringes (World Precision Instruments), with 33 gauge needles, attached to a UltraMicroPump (UMP3) with SYS-Micro4 Controller (World Precision Instruments).

\section{Immunohistochemistry}

$\mathrm{CTb}+$ Fos experiment. Immediately following the behavioral test, we deeply anesthetized rats with isoflurane and transcardially perfused them with $\sim 100 \mathrm{ml}$ of $0.1 \mathrm{M}$ PBS followed by $\sim 400 \mathrm{ml}$ of $4 \%$ PFA in $0.1 \mathrm{M}$ sodium phosphate, $\mathrm{pH}$ 7.4. We removed brains and postfixed them in $4 \%$ PFA for $2 \mathrm{~h}$, then transferred them to $30 \%$ sucrose in $0.1 \mathrm{M}$ sodium phosphate, $\mathrm{pH} \mathrm{7.4,} \mathrm{for} 48 \mathrm{~h}$ at $4^{\circ} \mathrm{C}$. We froze brains on dry ice and stored them at $-80^{\circ} \mathrm{C}$ until sectioning. We cut serial $(40 \mu \mathrm{m})$ coronal sections using a Leica Microsystems cryostat and stored sections in $0.1 \mathrm{~m}$ sodium phosphate, $\mathrm{pH} 7.4$, containing $1 \%$ sodium azide at $4^{\circ} \mathrm{C}$.
$C T b$ injection site verification. Immunohistochemical procedures were based on our previously published work (Marchant et al., 2009, 2014). We selected a 1-in-4 series of sections from the NAc shell of each rat, and immunofluorescence was used to determine CTb injection sites. We repeatedly rinsed free-floating sections in PBS $(3 \times 10$ min washes $)$ and incubated them for $2 \mathrm{~h}$ in PBS containing $0.5 \%$ Triton X-100 (PBS-tx) with $10 \%$ normal horse serum (NHS). We then incubated all sections for at least $48 \mathrm{~h}$ at $4^{\circ} \mathrm{C}$ in goat anti-CTb primary antibody (1:5000, List Biological Laboratories, 703), and mouse-anti neuronal nuclei primary antibody (1:2000, Millipore, MAB377) diluted in PBS-tx with $2 \%$ NHS. We washed off unbound primary antibodies with PBS and incubated the sections for $2-4 \mathrm{~h}$ in PBS-tx with $2 \%$ NHS and donkey anti-goat AlexaFluor-488 (1:2000; Jackson ImmunoResearch Laboratories, 705545-147) and donkey anti-mouse AlexaFluor-594 (1:2000; Jackson ImmunoResearch Laboratories, 715-585-151). We then rinsed sections in PBS, mounted onto gelatin-coated glass slides, air-dried, and coverslipped with Mowiol (Millipore).

Fos protein and $\mathrm{CTb}$ double labeling. We processed a 1-in-4 series of vmPFC, PVT, BLA, and vSub for immunohistochemical detection of Fos protein and CTb. We rinsed free-floating sections for $30 \mathrm{~min}$ in PBS, followed by two 30 min washes in 50\% ethanol with the second wash containing 3\% hydrogen peroxide and then incubated the sections for 30 min in a blocking solution containing $5 \%$ NHS in PBS. We then incubated sections for at least $48 \mathrm{~h}$ at $4^{\circ} \mathrm{C}$ in PBS-tx with $2 \%$ NHS, rabbit anti-c-Fos primary antibody (1:8000, Cell Signaling Technology, Phospho-c-Fos, 5348S) and goat anti-CTb primary antibody (1:5000, List Biological Laboratories, 703). Following primary incubation, we rinsed sections in PBS and incubated for $2 \mathrm{~h}$ in biotinylated donkey anti-rabbit IgG (1:2000, Jackson ImmunoResearch Laboratories, 711065-152) diluted in 2\% NHS PBS-tx. We rinsed off the secondary antibody with $\mathrm{PBS}$ and incubated the sections for $1 \mathrm{~h}$ in $\mathrm{ABC}$ reagent (Vector Laboratories). Following this step, we incubated sections in $0.1 \mathrm{M}$ sodium acetate with $0.025 \% \mathrm{DAB}$ in $2 \%$ nickel sulfate containing $2 \mathrm{mg} / \mathrm{ml}$ D-glucose and $0.4 \mathrm{mg} / \mathrm{ml} \mathrm{ammonium} \mathrm{chloride} \mathrm{for} 10 \mathrm{~min}$ before adding glucose oxidase $(0.2 \mu \mathrm{l}$ per milliliter of solution) to visualize the Fos protein. We stopped the reaction after $10 \mathrm{~min}$ with sodium acetate washes. We then rinsed sections in PBS and processed them again in a similar manner, using biotinylated donkey anti-goat IgG (1:2000, Jackson ImmunoResearch Laboratories, 705-065-003) as the secondary antibody for CTb. The DAB step of this reaction occurred without nickel sulfate to visualize $\mathrm{CTb}$ as a brown reaction product $(6.5 \mathrm{~min}$ reaction time). We next mounted the slides onto gelatin-coated glass slides. Finally, we dehydrated the slides through a graded series of alcohol concentrations (30\%, 60\%, 90\%, 95\%, 100\%, 100\% ethanol), cleared with Citrasolv (Fisher Scientific), and coverslipped them with Permount (Fisher Scientific).

DREADD experiments. Following the behavioral testing, we perfused the rats as above and processed the tissue for HA immunoreactivity. We selected a 1-in-4 series of sections from NAc shell and vSub of each rat and used immunofluorescence to determine the total number of KORD (HA-positive) neurons in vSub. We repeatedly rinsed free-floating sections in PBS $(3 \times 10$ min washes $)$ and incubated for $2 \mathrm{~h}$ in PBS containing PBS-tx with $10 \%$ NHS. We then incubated all sections for at least $48 \mathrm{~h}$ at $4^{\circ} \mathrm{C}$ in rabbit anti-HA primary antibody $(1: 1000$, Cell Signaling Technology, C29F4) diluted in PBS-tx with $2 \%$ NHS. We washed off the unbound primary antibodies with PBS and then incubated the sections for $2-4 \mathrm{~h}$ in PBS-tx with 2\% NHS and donkey anti-rabbit AlexaFluor-594 (1:2000; Jackson ImmunoResearch Laboratories, 711-585-152). We then rinsed sections in PBS, and stained with DAPI (1:1000) for 5 min before mounting onto gelatin-coated glass slides, air-dried, and coverslipped with Mowiol (Millipore).

\section{Image acquisition and neuronal quantification}

For $\mathrm{CTb}+$ Fos, we digitally captured bright-field images of immunoreactive (IR) cells in the different brain areas using an EXi Aqua camera (QImaging) attached to a Zeiss Axio Imager M2, with the $10 \times$ objective. We captured and analyzed the images using iVision (Biovision). Each analyzed image was derived from 5 images captured at different focal planes and then digitally merged using iVision, giving a single image of 
in-focus cells. For each rat, we quantified cells in the same hemisphere as the $\mathrm{CTb}$ injection. We quantified images of vmPFC ( 3 sections: bregma $3.72 \mathrm{~mm}$ to $2.76 \mathrm{~mm}$ ), PVT (6 sections: bregma $-1.32 \mathrm{~mm}$ to -3.48 $\mathrm{mm}$ ), BLA (4 sections: bregma -2.16 to $-3.48 \mathrm{~mm}$ ), and vSub (2 sections: bregma $-5.76 \mathrm{~mm}$ to $-6.0 \mathrm{~mm}$ ), by first calculating the area size by outlining the nucleus borders and then manually counting CTb-IR, Fos-IR, and CTb+Fos-IR cells. We present our data as total counts per square millimeter to permit meaningful comparisons between brain regions of different sizes. The counting was performed by an observer that was blind to the experimental conditions.

For HA (KORD), we digitally captured dark-field images of IR cells in vSub using the same microscope with the $5 \times$ objective. For each rat, we manually quantified IR cells over 5 sections of vSub (bregma $-5.4 \mathrm{~mm}$ to $-6.2 \mathrm{~mm}$ ) in both hemispheres. Counting was performed by an observer that was blind to the experimental conditions. For the DREADD experiments, we excluded rats in the SalB condition that had low KORD $(n=3)$ or hM3D $(n=3)$ expression $(<20$ HA-positive neurons per square millimeter in one or both hemispheres).

\section{Ex vivo electrophysiology}

We used P rats $(n=8)$ that had undergone $5 \mathrm{~d}$ of home-cage access to $20 \%$ alcohol and injected bilateral AAV5-Cre in NAc shell and AAV1DIO-KORD in vSub (as described above). We performed ex vivo electrophysiology 6-7 weeks after the surgery. On the recording days, we deeply anesthetized the rats with isoflurane (90-120 s) and then transcardially perfused them with ice-cold solution containing the following (in $\mathrm{mM}$ ): 220 sucrose, $28 \mathrm{NaHCO}_{3}, 2.5 \mathrm{KCl}, 1.25 \mathrm{NaH}_{2} \mathrm{PO}_{4}, 0.5 \mathrm{CaCl}_{2}, 7 \mathrm{MgCl}_{2}, 7$ glucose, 3 sodium pyruvate, and 1 ascorbic acid, saturated with $95 \% \mathrm{O}_{2}$ and $5 \% \mathrm{CO}_{2}$ (Harnett et al., 2012). We cut transverse slices containing vSub in the ice-cold solution and incubated the slices $30 \mathrm{~min}$ at $35^{\circ} \mathrm{C}$ in the same solution (Dougherty et al., 2012). Slices were allowed to recover for a minimum of $1 \mathrm{~h}$ at room temperature in ACSF containing the following (in mM): $126 \mathrm{NaCl}, 2.5 \mathrm{KCl}, 1.2 \mathrm{MgCl}_{2}, 2.4 \mathrm{CaCl}_{2}, 1.2$ $\mathrm{NaH}_{2} \mathrm{PO}_{4}, 21.4 \mathrm{NaHCO}_{3}, 11.1$ glucose, $3 \mathrm{Na}$-pyruvate, $1 \mathrm{Na}$-ascorbate. We recorded from the slices while they were bath perfused $(2.5 \mathrm{ml} / \mathrm{min})$ at $32^{\circ} \mathrm{C}-35^{\circ} \mathrm{C}$ in the same ACSF solution. The intracellular solution contained the following (in $\mathrm{mM}$ ): $115 \mathrm{~K}$-gluconate, $20 \mathrm{KCl}, 1.5 \mathrm{MgCl}_{2}, 10$ HEPES, 0.025 EGTA, $2 \mathrm{Mg}$-ATP, $0.2 \mathrm{Na}_{2}$-GTP, $10 \mathrm{Na}_{2}$-phosphocreatine, $\mathrm{pH} 7.2-7.3, \sim 285 \mathrm{mOsm} / \mathrm{kg}$.

We identified KORD-expressing (mCitrine+) cells using scanning disk confocal microscopy (Olympus FV1000) and used differential interference contrast optics to patch the neurons. We performed whole-cell current-clamp recordings in visually identified pyramidal neurons in vSub. We injected current steps during the recording session $(500 \mathrm{~ms}$ at $0.1 \mathrm{~Hz}, 50-330 \mathrm{pA})$. For each cell that we recorded, we generated inputoutput curves under baseline conditions and following superfusion of vehicle (5\% DMSO) for 5-10 min, and finally SalB (100 nM) for 5-10 min (Vardy et al., 2015; Marchant et al., 2016). We excluded recordings if series resistance or input resistance changed $>10 \%$ during recording session. We used an Axopatch 200B amplifier (Molecular Devices) and Axograph X software (Axograph Scientific) to record and collect the data, which were filtered at $10 \mathrm{kHz}$ and digitized at $4-20 \mathrm{kHz}$.

\section{Specific experiments}

Experiment 1: Effect of context-induced relapse of alcohol seeking after punishment-imposed abstinence on Fos expression in projections to NAc shell $(\mathrm{n}=24)$. We trained rats to self-administer alcohol in Context A and subsequently punished alcohol-reinforced responding in Context $\mathrm{B}$. We gave all rats 7 punishment sessions before the context-induced relapse test, with the shock intensity increasing from 0.1 to $0.7 \mathrm{~mA}$ in 0.1 $\mathrm{mA}$ increments. Following punishment-imposed suppression of alcohol taking, we tested the rats in Context $\mathrm{A}$ (alcohol training context; $n=8$ ), Context B (punishment context; $n=8$ ), or did not test them (No-test group; $n=8$ ). Immediately after the 90 min test, we deeply anesthetized the rats with isoflurane and extracted their brains after perfusion. The No-test rats were taken directly from their home-cage and perfused on the same day as the other rats. We then processed brains for immunohistochemical detection of Fos protein and CTb. The number of rats we used for the Fos $+\mathrm{CTb}$ double-labeling measurement was lower than for the Fos measurement because we excluded rats with low CTb expression. Additionally, the number of rats for the Fos assay was not identical for the different brain regions because of loss of tissue during cryostat sectioning or during the immunohistochemistry assay.

Experiment 2: Effect of $\nu \mathrm{Sub}$ inactivation on context-induced relapse of alcohol seeking after punishment imposed abstinence $(\mathrm{n}=14)$. We trained rats to self-administer alcohol in Context $A$ and subsequently punished the alcohol-reinforced responding in Context $\mathrm{B}$. We gave all rats 7 punishment sessions before the context-induced relapse test, with the shock intensity increasing from $0.1 \mathrm{~mA}$ to $0.5 \mathrm{~mA}$ in $0.1 \mathrm{~mA}$ increments. On punishment days 6 and 7 , we kept the shock intensity at $0.5 \mathrm{~mA}$. We tested all rats in 90 min sessions in both Context $\mathrm{A}$ and Context $\mathrm{B}$ under extinction conditions over consecutive days (order counterbalanced). The groups were vSub muscimol+baclofen $(n=7)$ and vSub vehicle $(n=7)$.

Intracranial injections. We dissolved muscimol+baclofen (Tocris Bioscience; concentration: $0.06+0.6 \mathrm{~mm}$ or $3.6+64.1 \mathrm{ng}$ in $0.5 \mu$ l per side) in sterile saline. The injectors extended $1 \mathrm{~mm}$ below the tips of the guide cannulas. We injected vehicle ( $0.9 \%$ saline) or muscimol+baclofen over $1 \mathrm{~min}$ and left the injectors in place for $1 \mathrm{~min}$; we tested the rats 5-10 min after injections. We used a Harvard Apparatus syringe pump connected to $10 \mu \mathrm{l}$ Hamilton syringes attached via polyethylene-50 tubing to 30 gauge injectors for all intracranial injections. Following the final test, we deeply anesthetized rats with isoflurane and removed their brains and stored them in $10 \%$ formalin. We sectioned brains at $40 \mu \mathrm{m}$ using a Leica Microsystems cryostat and stained sections with cresyl violet to verify the placement of the cannulas.

Experiment 3: Effect of SalB injections on context-induced relapse in rats expressing KORD in $v S u b \rightarrow N A c$ shell neurons $(\mathrm{n}=29)$. We injected the rats with AAV5-Cre into NAc shell and AAV1-DIO-KORD into vSub after the home-cage phase. We then trained the rats to self-administer alcohol in Context A and subsequently punished the alcohol-reinforced responding in Context $\mathrm{B}$. We habituated the rats to the DMSO injections by giving them $0.2 \mathrm{ml}$ (s.c.) injections $10 \mathrm{~min}$ before 3 sessions in training Context A and 1 session in punishment Context B. We gave all rats 6 punishment sessions, with the shock intensity increasing from $0.1 \mathrm{~mA}$ to $0.5 \mathrm{~mA}$ in $0.1 \mathrm{~mA}$ increments. On punishment day 6 , all rats that had $>15$ active lever presses on punishment day 5 received $0.6 \mathrm{~mA}$; the rest of the rats received $0.5 \mathrm{~mA}$ on punishment day 6 . For the relapse tests, we used an experimental design that included the within-subjects factors of test context (Context A, Context B) and the between-subjects factor of SalB dose (vehicle [DMSO], $15 \mathrm{mg} / \mathrm{kg}$, s.c; injection volume $0.5 \mathrm{ml} / \mathrm{kg} ; 10 \mathrm{~min}$ pretreatment time). We tested the rats for context-induced relapse under extinction conditions in Contexts A and B (30 min duration) over $2 \mathrm{~d}$. We counterbalanced the order of testing in Contexts A and B. After these tests, we gave the rats an additional Context B punishment session $(0.5$ $\mathrm{mA}$ ). We then retrained them to self-administer alcohol in Context A (3 daily sessions), repunished them in Context B (3 sessions; 0.3, 0.4, 0.5 $\mathrm{mA}$ ), and retested them under extinction conditions in Contexts $\mathrm{A}$ and $\mathrm{B}$ with the drug condition reversed. We added a retest component to Experiment 3 because in unpublished studies we observed a success rate of $\sim 60 \%$ for high HA expression in both hemispheres. Thus, we were hoping that, with repeated testing, we will have a sufficient number of subjects for a complete within-subjects assessment of the effect of SalB versus vehicle on context-induced relapse after punishment. We ended up not using this experimental approach because initial inspection of the data showed both an order effect (higher active lever presses during the second test than during the first test) and an unexpected dissociation of the effect of SalB on the first versus the second test (see Results and Discussion).

Experiment 4: Effect of SalB injections on context-induced relapse in rats expressing $h M 3 D$ in $v S u b \rightarrow N A c$ shell neurons $(\mathrm{n}=24)$. The goal of this control experiment was to determine whether SalB injections will have an effect on context-induced relapse in rats injected with AAV5-Cre in NAc shell and a different DREADD (AAV5-DIO-hM3D) in vSub that is not activated by SalB. The procedures and experimental design were identical to those described for Experiment 3, except that we injected the rats with AAV5-DIO-hM3D into the vSub after the home-cage phase and only tested them once. We chose to use AAV5-DIO-hM3D as a control virus 
instead of typical fluorescent protein controls (e.g., AAV5-DIO-YFP, AAV5-DIO-GFP) because this viral construct, like AAV1-DIO-KORD, expresses a membrane-targeted, ligand-activated designer receptor that has no effect on basal neuronal activity in the absence of the ligand.

\section{Statistical analysis}

We analyzed the data separately for the four phases: (1) home-cage alcohol intake; (2) Context A training; (3) Context B punishment; and (4) context-induced relapse tests. For the relapse tests, the dependent variable was the total number of active lever presses or number of minutes to first active lever press (latency); the number of inactive lever presses during testing was used as a covariate in the analyses. We analyzed the immunohistochemical data with cell counts per square millimeter of a given brain region as the dependent variable. In Experiment 1, we analyzed the number of Fos-IR, CTb-IR, and CTb + Fos cells using a mixed ANOVA with the within-subjects factor of brain region and the betweensubjects factor of test context (Context A, Context B, No-test). We subsequently analyzed main effects using one-way ANOVAs. In Experiment 2 (vSub inactivation), we analyzed the relapse test data using the withinsubjects factor of test context (Context A, Context B) and the betweensubjects factor of drug (vehicle, muscimol+baclofen). In Experiments 3 and 4 , we analyzed the relapse test data using the within-subjects factors of test context (Context A, Context B) and the between-subjects factor of SalB (vehicle, $15 \mathrm{mg} / \mathrm{kg}$ ). In the ex vivo electrophysiology experiments, we analyzed the number of action potentials using the within-subjects factors of current (50-330 pA in $20 \mathrm{pA}$ steps) and SalB concentration $(0$, $100 \mathrm{~nm}$ ) and the between-subjects factor of KORD expression (KORDpositive or KORD-negative).

We performed all statistical analyses using IBM SPSS version 21 and followed up on significant main or interaction effects $(p<0.05)$ with Fisher PLSD post hoc tests. We present the data in the figures as mean \pm SEM.

\section{Results}

\section{Training and punishment phases}

The alcohol-preferring P rats consumed high amounts of alcohol in the home-cage intermittent-access choice phase and reliably self-administered alcohol in Context A under the FR-1, $20 \mathrm{~s}$ timeout and VI-30 schedules of reinforcement (Fig. 1). During punishment in Context $\mathrm{B}$, the rats decreased alcohol selfadministration when we increased the shock intensity (Fig. 1).

\section{Effect of context-induced relapse after punishment-imposed abstinence on neuronal activity in neurons that project to NAc shell}

In Experiment 1, we combined retrograde tracing via CTb (injected into NAc shell), with measurement of Fos in the projection areas, to determine whether context-induced relapse to alcohol seeking after punishment-imposed abstinence is associated with activation of vSub, vmPFC, PVT, and BLA neurons projecting to NAc shell. Below, we first present the behavioral data and then describe the neuroanatomical data.

\section{Context-induced relapse test (behavioral data)}

We observed context-induced relapse to alcohol seeking in Context A after punishment-imposed abstinence in Context B (Fig. $2 C$ ). An ANCOVA of active lever presses (inactive lever presses as covariate) showed a significant effect of test context $\left(F_{(1,13)}=\right.$ $40.7, p<0.01$ ). An analysis of the latency (time to first active lever press) data showed a significant effect of test context $\left(F_{(1,14)}=\right.$ 14.0, $p<0.01$ ); Figure 2D).

Fos data

Our initial analysis using the within-subjects factor brain region (vSub, BLA, PVT, and vmPFC) and the between-subjects factor test context showed a significant interaction between the two factors $\left(F_{(6,54)}=3.8, p<0.01\right)$. Subsequent one-way ANOVAs within each brain region showed a significant effect of test context in each brain region (vSub: $F_{(2,18)}=9.6$; BLA: $F_{(2,19)}=6.2$; PVT: $F_{(2,19)}=10.5$; and vmPFC: $F_{(2,19)}=6.9 ; p$ values $\left.<0.01\right)$. Post hoc analyses showed significant differences between Context A group compared with Context B and No-test groups for vSub, BLA, and PVT ( $p$ values $<0.05$; Fig. $2 F$ ). In the vmPFC, the number of Fos-IR in Context A group was significantly different from the No-test group $(p<0.01)$ but not Context B group $(p=$ 0.09; Fig. $2 F)$.

\section{$C T b+$ Fos data}

There were no differences observed in the total number of CTb-IR cells across groups ( $p$ values $>0.1$; Fig. $2 G$ ). Analysis of the $\mathrm{CTb}+$ Fos-IR counts showed a significant interaction between brain region (within-subjects factor) and test context (between-subjects factor) $\left(F_{(4,30)}=11.4, p<0.01\right)$. Subsequent one-way ANOVAs showed a significant effect of test context on the number of CTb+Fos-IR cells in vSub $\left(F_{(2,16)}=23.7, p<\right.$ $0.01)$ but not BLA, PVT, or vmPFC ( $p$ values $>0.1)$. Post hoc analyses of the vSub counts showed higher $\mathrm{CTb}+$ Fos-IR cells in rats tested in Context A compared with rats tested in Context B or the No-test group ( $p$ values $<0.01$; Fig. $2 H$ ).

In summary, the data in Experiment 1 confirm our previous results that exposure to the original alcohol-associated training context, after punishment-imposed abstinence in a different context, provokes relapse to alcohol seeking (Marchant et al., 2013). More importantly, the $\mathrm{CTb}+$ Fos double-labeling data show that context-induced relapse after punishment-imposed abstinence is associated with selective activation of vSub neurons that project to NAc shell.

\section{Effect of vSub inactivation on context-induced relapse to alcohol seeking after punishment-imposed abstinence}

In Experiment 2, we determined the causal role of vSub in context-induced relapse by reversible inactivation of vSub, using intracranial injections of $\mathrm{GABAa}+\mathrm{GABAb}$ receptor agonists (muscimol+baclofen) (McFarland and Kalivas, 2001), before the context-induced relapse test.

We found that vSub inactivation decreased context-induced relapse to alcohol seeking after punishment-imposed abstinence (Fig. 3B). Analysis of active lever presses (inactive lever presses as a covariate) showed a significant interaction between test context (Context A, Context B; within-subjects) and drug (muscimol+baclofen, vehicle; between-subjects) $\left(F_{(1,10)}=7.8\right.$, $p<0.05)$. Analysis of latency to first active lever press revealed a significant main effect of test context $\left(F_{(1,12)}=9.0, p<0.05\right)$ but no significant interaction between drug and test context $(p>$ 0.05 ; Fig. $3 B$ ). These data indicate that vSub inactivation decreases alcohol seeking in Context A without affecting the latency to initiate alcohol seeking during the relapse tests.

The results of Experiment 2, combined with the results of Experiment 1 , indicate that neuronal activity in vSub plays a critical role in context-induced relapse after punishment-imposed abstinence.

\section{Ex vivo electrophysiology validation of the inhibitory action of SalB in KORD expressing vSub $\rightarrow$ NAc shell neurons}

We used ex vivo electrophysiology to verify that our double-virus "retro-DREADD" procedure (Marchant et al., 2016) permits DREADD-mediated selective inhibition of vSub $\rightarrow$ NAc shell neurons. We found that bath application of SalB decreased spike rate induced by direct current injection in KORD-positive neurons (identified by expression of mCitrine) but not KORDnegative neurons. The statistical analysis consisted of the 
A

Behavioral procedure

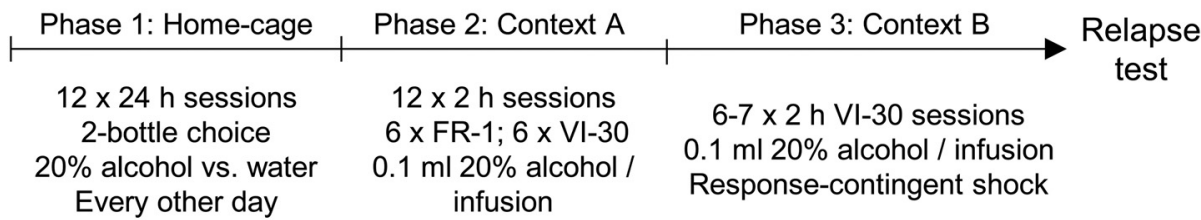

B Home-cage drinking
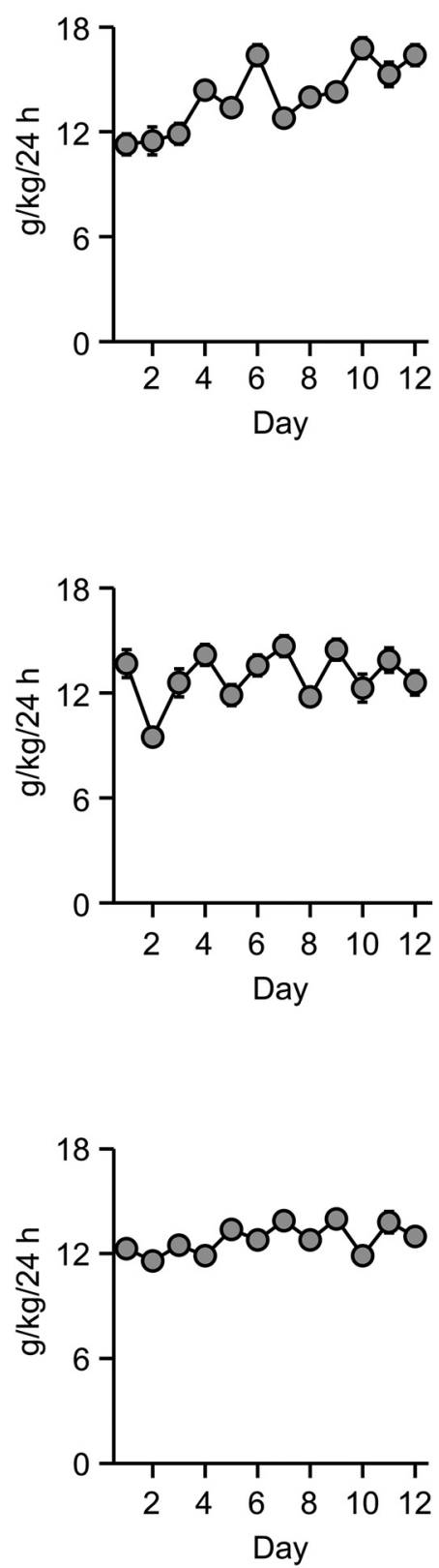

Context A: Self-administration

Context B: Punishment

\section{Experiment 1}

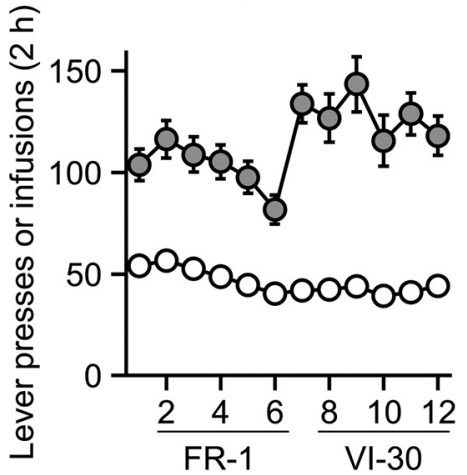

Reinforcement schedule

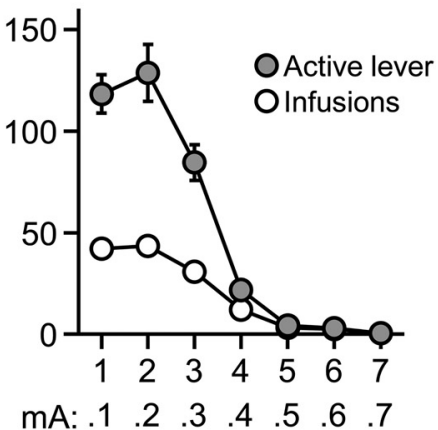

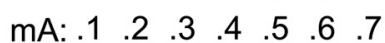
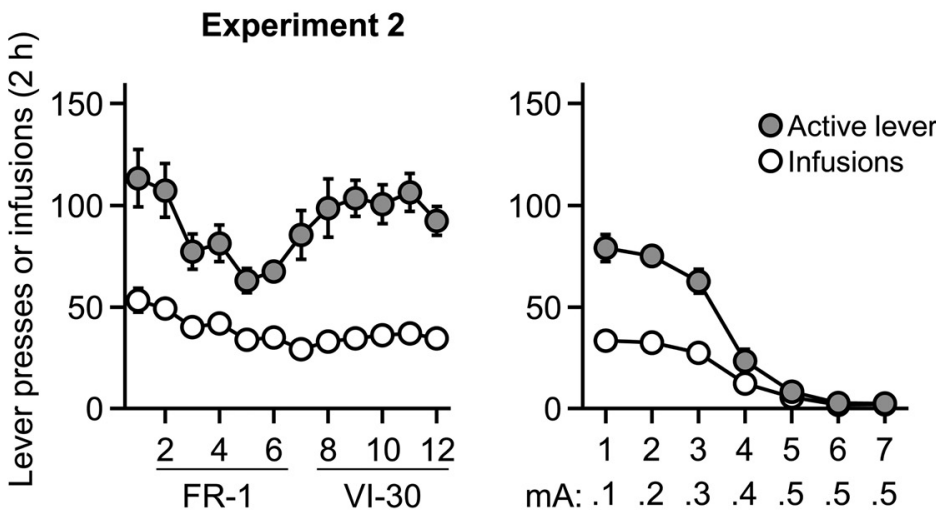

Reinforcement schedule

Experiments 3-4
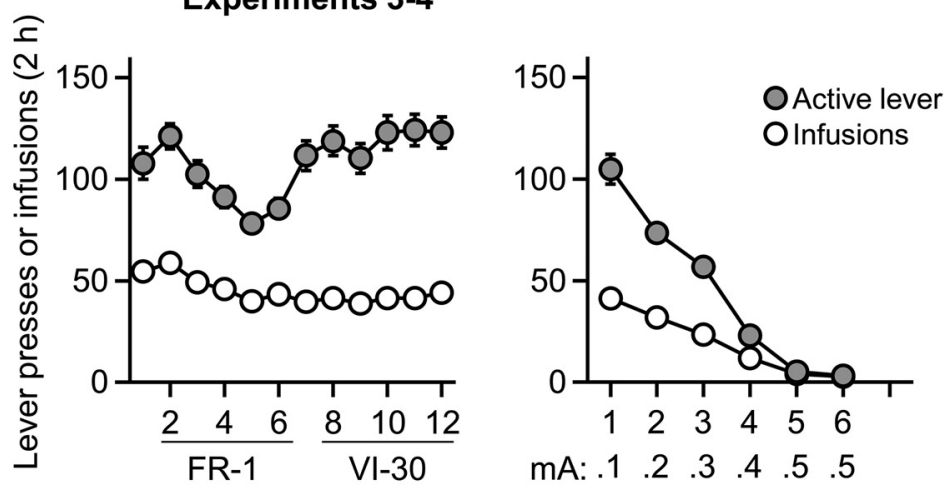

Reinforcement schedule

Figure 1. Home-cage intake, alcohol self-administration in Context $\mathrm{A}$, and punishment of alcohol self-administration in Context $\mathrm{B}$. $A, 0$ utline of the experimental procedure before the context-induced relapse tests. FR, Fixed-ratio. B, Alcohol intake (grams per kilogram) during home-cage access to $20 \%$ alcohol. Context A active lever presses and infusions under the FR-1 20 s timeout and VI- 30 schedules of reinforcement. Context $B$ active lever presses and infusions. Data are mean $\pm \mathrm{SEM} ; n=91$. Experiment 1 shock punishment range, $0.1-0.7 \mathrm{~mA}, n=$ 24. Experiment 2 shock punishment range, $0.1-0.5 \mathrm{~mA}, n=14$. Experiments 3 and 4 shock punishment range, $0.1-0.5 \mathrm{~mA}, n=53$. 
A

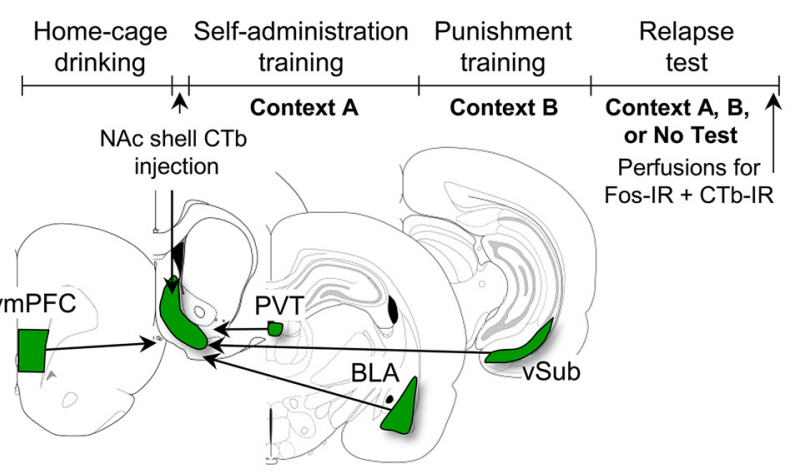

C Context-induced relapse of alcohol seeking

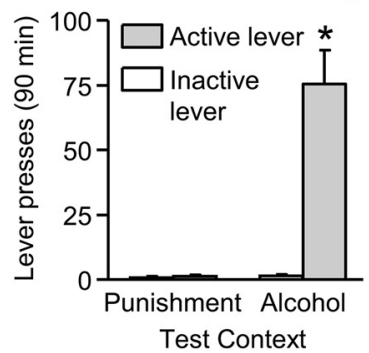

F Total number of Fos-IR neurons

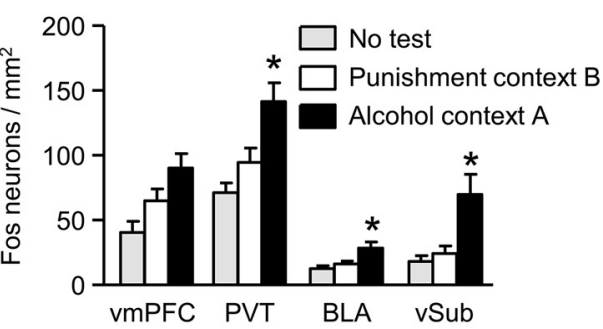

G Total number of CTb-IR neurons

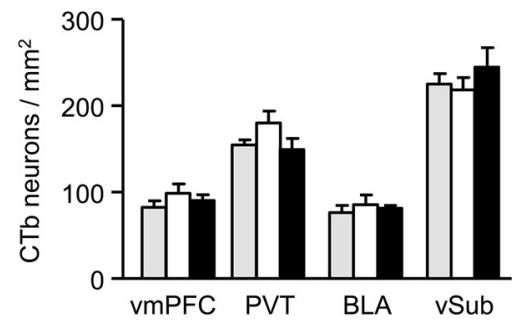

H Total number of CTb+Fos-IR neurons

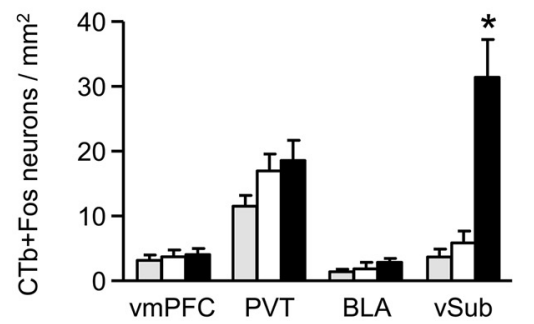

B NAc shell CTb injections

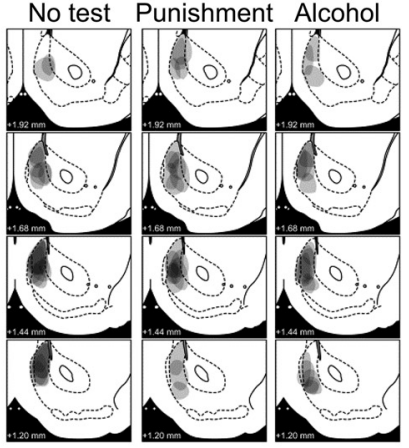

E Representative CTb injection in Nac shell

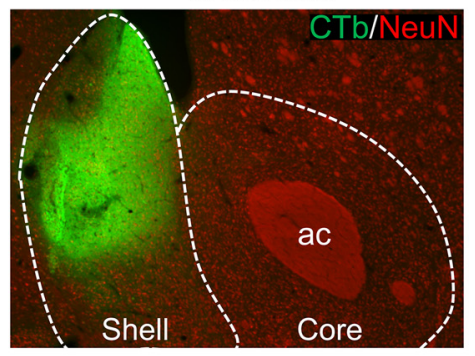

Representative CTb+Fos images
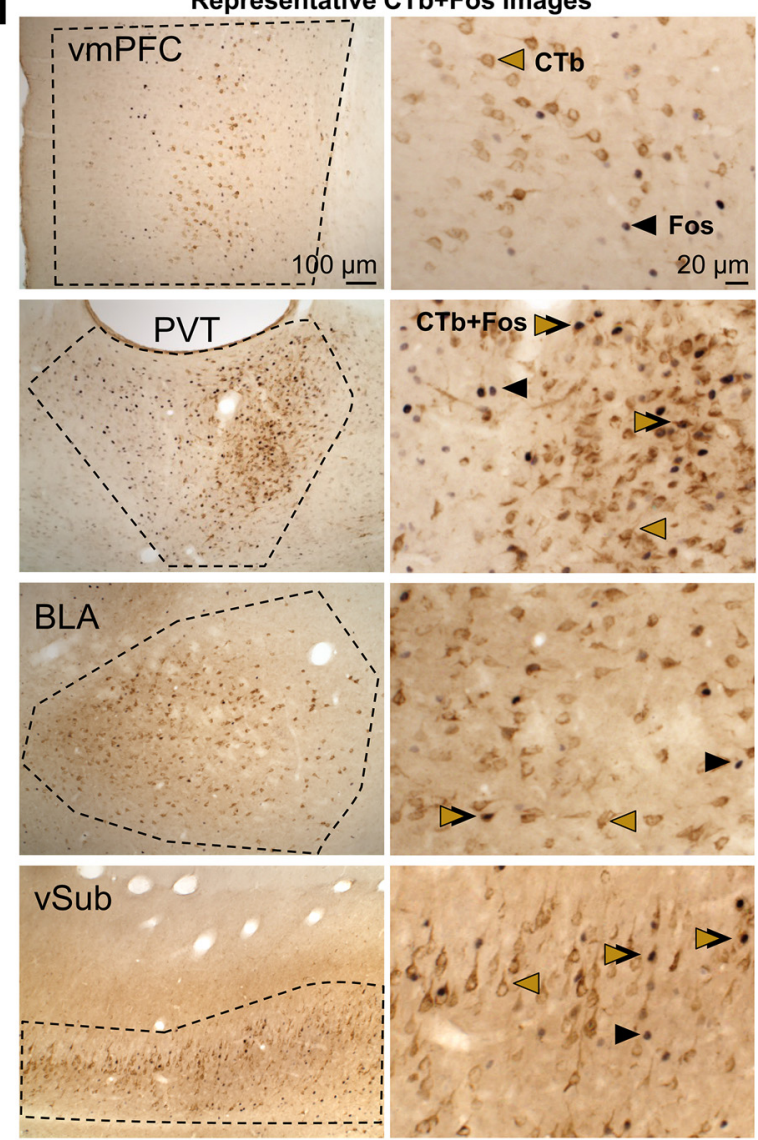

Figure 2. Context-induced relapse after punishment-imposed abstinence is associated with selective activation of the vSub $\rightarrow$ NAc projection. $\boldsymbol{A}$, Outline of experimental procedure and schematic of the inputs to NAc shell assessed in Experiment 1.B, Representative plots of the spread of CTb injections for the three groups. C, Data are mean \pm SEM; number of active and inactive lever presses during the relapse test. $\boldsymbol{D}$, Data are mean \pm SEM; latency to first active lever press during the relapse test. $\boldsymbol{E}$, Photomicrograph of (Tb injection contained to the NAc shell (green) with background staining of neuronal nuclei (NeuN). F, Data are mean \pm SEM; number of Fos-IR neurons per square millimeter in vmPFC, PVT, BLA, and vSub in rats tested in either Context A, Context $B$, or not tested. G, Data are mean \pm SEM; number of CTb-IR neurons per square millimeter in vmPFC, PVT, BLA, and vSub. $\boldsymbol{H}$, Data are mean \pm SEM; number of CTb + Fos-IR neurons per square millimeter in vmPFC, PVT, BLA, and vSub. ${ }^{*} p<0.05 . n=5-8$ per group. $I$, Representative photomicrographs of CTb and Fos-IR in each brain region analyzed. *Different from the Punishment condition $(\boldsymbol{C}, \boldsymbol{D})$ or from the Punishment and No-test conditions $(\boldsymbol{F}, \boldsymbol{H}), p<0.05$. 
A

\begin{tabular}{c|cc|c}
$\begin{array}{c}\text { Home-cage } \\
\text { drinking }\end{array}$ & $\begin{array}{c}\text { Self-administration } \\
\text { training }\end{array}$ & $\begin{array}{c}\text { Punishment } \\
\text { training }\end{array}$ & $\begin{array}{c}\text { Relapse } \\
\text { test }\end{array}$ \\
\hline $\begin{array}{c}\text { Intracranial } \\
\text { cannulas surgery }\end{array}$ Context A & Context B & $\begin{array}{c}\text { Context A \& B } \\
\text { Vehicle or Mus+Bac } \\
\text { vSub injections }\end{array}$
\end{tabular}

\section{B Effect of vSub inactivation on context-induced} relapse to alcohol seeking
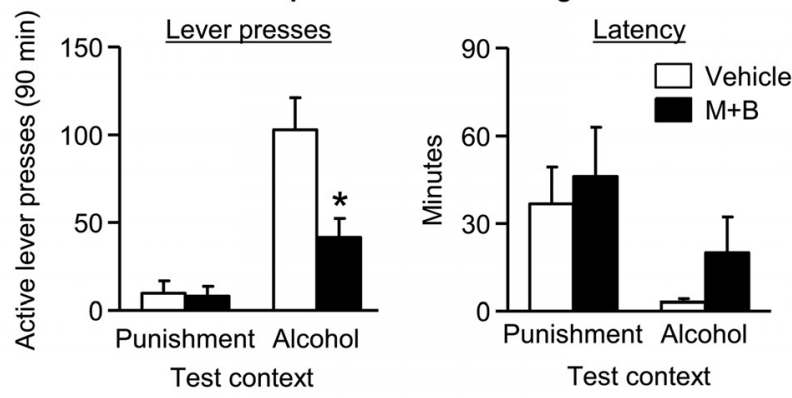

C

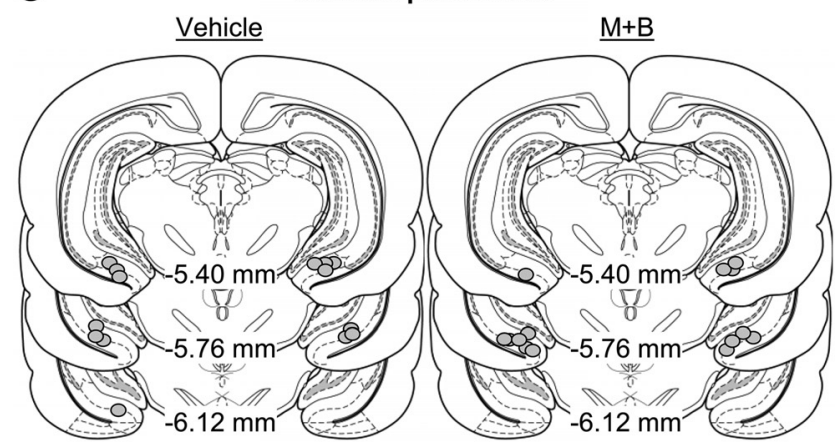

Figure 3. vSub inactivation decreases context-induced relapse to of alcohol seeking after punishment-imposed abstinence. $\boldsymbol{A}$, Outline of experimental procedure. $\boldsymbol{B}$, Data are mean \pm SEM; number of active lever presses (left) and active lever latency (right) during the relapse test. $n=7$ per group. C, Approximate cannula placements ( $\mathrm{mm}$ from bregma) of the injector tips for vSub. M, muscimol; B, baclofen. *Different from the Vehicle condition, $p<0.05$.

between-subjects factor of KORD expression (KORD-positive, $n=8$ cells; KORD-negative, $n=7$ cells; from 8 rats in total), and the within-subjects factors current (50-330 pA in $20 \mathrm{pA}$ steps) and SalB concentration $(0,100 \mathrm{nM})$. The statistical analysis showed a significant current $X$ SalB concentration $X$ expression interaction $\left(F_{(28,364)}=4.7, p<0.01\right.$; Fig. $\left.4 D, E\right)$. The results of our electrophysiology study show selective inhibition of neuronal firing by SalB in KORD-positive vSub $\rightarrow$ NAc shell neurons, but not KORD-negative neurons, setting the stage for Experiment 3 (described below) on the effect of inhibition of the vSub $\rightarrow$ NAc shell projection on context-induced relapse after punishmentimposed abstinence.

Effect of chemogenetic inhibition of vSub $\rightarrow$ NAc shell projection neurons on context-induced relapse of alcohol seeking after punishment-imposed abstinence

In Experiment 3, we used the "retro-DREADD" dual-virus approach (Marchant et al., 2016) to restrict expression of KORD in vSub to neurons projecting to NAc shell (Fig. $5 B$ ) to determine the causal role of the $\mathrm{vSub} \rightarrow \mathrm{NAc}$ shell projection in contextinduced relapse after punishment-imposed abstinence. Based on the results of Experiments 1 and 2, we predicted that systemic injections of the designer drug SalB before the relapse test, which will selectively inhibit neuronal activity in the vSub $\rightarrow$ NAc shell projection during the test, would decrease context-induced relapse.

The mean \pm SEM number of HA-positive neurons per hemisphere in the vehicle $(n=16)$ and SalB $(n=13)$ group was $27.5 \pm$ 4.3 and $49.8 \pm 4.4$, respectively. We eliminated 3 rats from the SalB group because of low KORD expression (the mean \pm SEM number of HA-positive neurons in the lowest hemisphere of these rats was $7.0 \pm 3.2$ ). We did not exclude any rats from the vehicle group to maintain sufficient statistical power and because there was no difference in alcohol self-administration in Context A or punishment responding in Context B between rats that were injected with vehicle during the first context-induced relapse test versus the high KORD-expressing rats that were injected with SalB during this test (data not shown).

We found that SalB decreased context-induced relapse on the first relapse test (Fig. 5C). The analysis of active lever presses of this test included the between-subjects factor of SalB dose (vehicle, $15 \mathrm{mg} / \mathrm{kg}$ ) and the within-subjects factors of test context (Context A, Context B) with inactive lever presses as the covariate. This analysis showed significant main effects of test context $\left(F_{(1,25)}=47.5, p<0.01\right)$ and SalB dose $\left(F_{(1,25)}=5.6, p<0.05\right)$, and a significant interaction between the two factors $\left(F_{(1,25)}=\right.$ $4.9, p<0.05)$. The statistical analysis of the latency for the first response showed a significant main effect of test context $\left(F_{(1,27)}=\right.$ 34.6, $p<0.01$ ) but no significant main effect of SalB dose or interaction between the two factors (Fig. $5 C$ ). These data show that, during the first relapse test, inhibition of the vSub $\rightarrow$ NAc shell projection decreased context-induced relapse to alcohol seeking but had no effect on the latency to the first response.

As described in Materials and Methods, at the end of Experiment 3 , we retrained, repunished, and retested the rats for contextinduced relapse. The retest conditions were the same as in the initial test, except that the rats injected with vehicle during the first test, were injected with SalB during the second test and vice versa. The retest condition included all rats injected with SalB on Test 1 and then injected with vehicle on Test $2(n=13)$ and a subgroup of rats $(n=6)$ injected with vehicle on Test 1 and SalB on Test 2 that were equated for vSub KORD expression to the first group ( $45.4 \pm 4.6 \mathrm{vs}$ $49.8 \pm 4.4$ HA-positive neurons per square millimeter). Unexpectedly, after additional exposure to alcohol and punishment, inhibition of the vSub $\rightarrow$ NAc shell projection with SalB had no effect on context-induced relapse. The mean \pm SEM number of active lever presses per $30 \mathrm{~min}$ in Contexts A and B after vehicle $(n=13)$ or SalB $(n=6)$ injections was $62.2 \pm 5.2$ and $65.8 \pm 14.8$, and the number of inactive lever presses was $1.0 \pm 0.5$ and $6.2 \pm 4.1$. The statistical analysis showed a significant effect of test context $\left(F_{(1,15)}=62.0, p<\right.$ 0.01 ) but no significant main effect of SalB dose or interaction between the two factors. Importantly, reanalysis of the Test 1 data in the same subsample of rats analyzed in Test 2 (i.e., equated for vSub KORD expression), SalB injections decreased context-induced relapse during the first test: mean \pm SEM of $58.5 \pm 9.6$ (vehicle) and $30.9 \pm 6.5$ (SalB) lever presses per $30 \mathrm{~min}\left(F_{(1,15)}=5.7, p<0.05\right)$.

Finally, in Experiment 4, we determined the effect of SalB injections on context-induced relapse in rats injected with AAV5Cre into NAc shell and with AAV5-DIO-hM3D into vSub, a different DREADD that is not activated by SalB (Armbruster et al., 2007). The procedures and experimental design of this control experiment were identical to those of the first test in Experiment 3. Three rats were eliminated from the SalB condition because of missing vSub sections or low expression. The mean \pm SEM number of lower and higher hemisphere hM3D-expressing vSub neurons per square millimeter in the SalB condition was $75.8 \pm 10.7$ and $98.2 \pm 10.5$, respectively. 
A

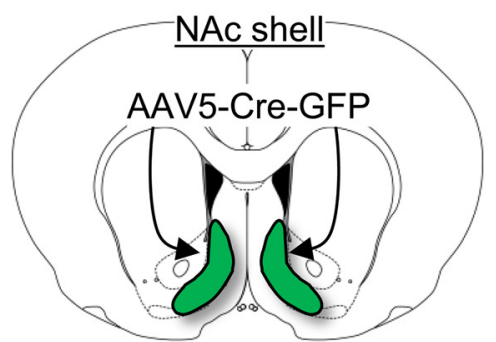

B

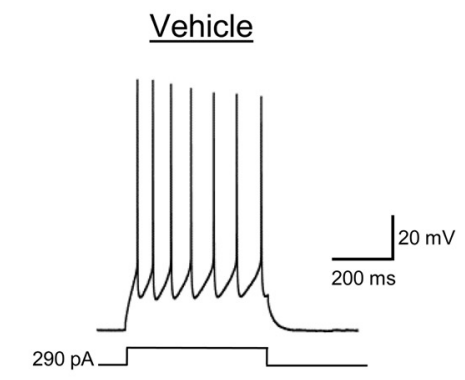

SalB (100 nM)

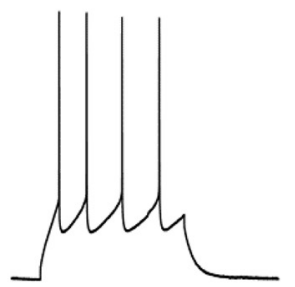

D KORD-positive neurons

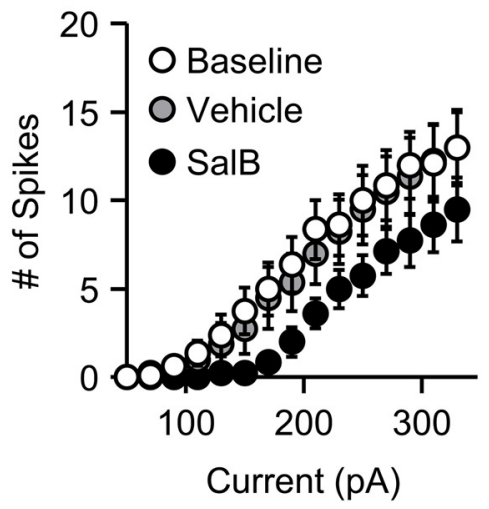

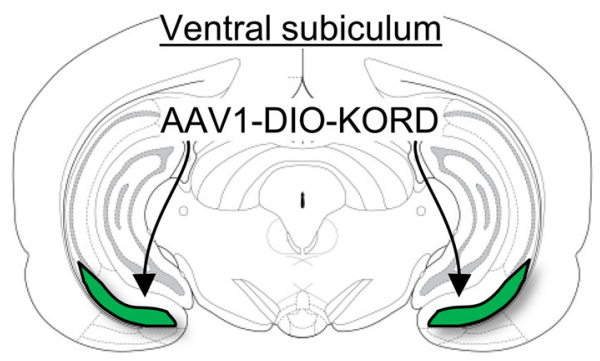

C KORD-negative neuron $\underline{\text { Vehicle }}$

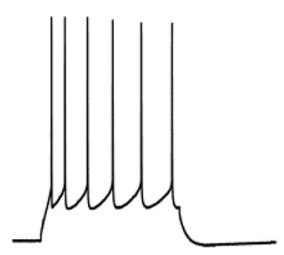

SalB (100 nM)

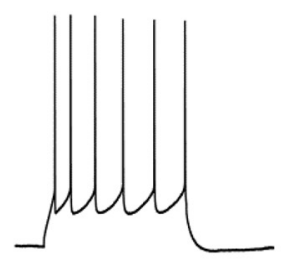

E KORD-negative neurons

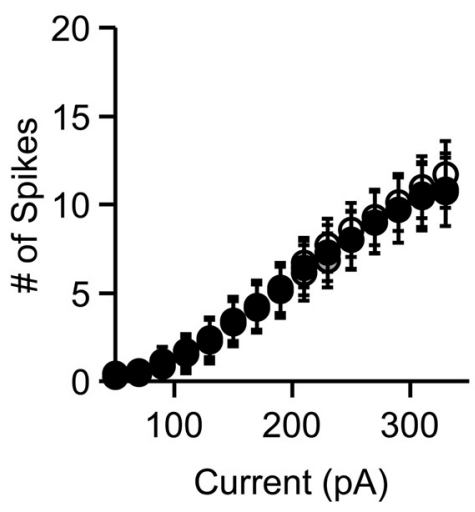

Figure 4. SalB inhibits neural activity in KORD-expressing vSub $\rightarrow$ NAc shell neurons. $A$, Schematic of AAV5-Cre injections in NAC shell and AAV1-DIO-KORD injections in vSub. $\boldsymbol{B}$, Example trace of action potentials evoked by current injection in KORD-positive neuron in the vehicle condition (top) and SaIB condition (bottom). $C$, Example trace of action potentials evoked by current injection in a KORD-negative neuron in the vehicle condition (top) and SaIB condition (bottom). $D$, Group data for firing frequency plotted as a function of current injection in KORD-positive vSub $\rightarrow$ NAc shell neurons; $n=8$. $E$, Group data for firing frequency plotted as a function of current injection in KORD-negative neurons; $n=7$.

In rats with vSub expression of hM3D, we found that SalB injections had no effect on context-induced relapse after punishment-imposed abstinence. The mean \pm SEM number of active lever presses in Context A were as follows: vehicle $(n=11)$, $29.5 \pm 5.6$; and SalB $(n=13), 34.1 \pm 7.0$. The mean \pm SEM number of active lever presses in Context B was as follows: vehicle $0.45 \pm 0.25$; SalB $0.46 \pm 0.18$. The statistical analysis showed a significant effect of test context $\left(F_{(1,20)}=25.2, p<0.01\right)$ but no other significant main or interaction effects. The statistical analysis on the latency for the first response showed a significant main effect of test context $\left(F_{(1,22)}=60.2\right.$, $p<0.01$ ) but no significant main effect of SalB dose or interaction between the two factors. These data show that SalB injections had no effect on context-induced relapse in rats expressing hM3D in $\mathrm{vSub} \rightarrow \mathrm{NAc}$ shell neurons.

Together, the results of Experiments 3 and 4 suggest a time-limited role of the $\mathrm{vSub} \rightarrow$ NAc shell projection in contextinduced relapse after punishment-imposed abstinence (see Discussion).

\section{Discussion}

We report four main findings. First, context-induced relapse after punishment-imposed abstinence was associated with selective activation of the $\mathrm{vSub} \rightarrow$ NAc shell projection. Second, reversible inactivation of vSub decreased context-induced relapse. Third, chemogenetic inhibition of the vSub $\rightarrow$ NAc shell projection decreased context-induced relapse, albeit to a lesser degree than vSub reversible inactivation. Fourth, the effect of chemogenetic inhibition of the $\mathrm{vSub} \rightarrow \mathrm{NAc}$ shell projection was designer-receptor specific and dependent on prior history of alcohol and punishment exposure. SalB had no effect on contextinduced relapse in rats expressing hM3D in the $\mathrm{vSub} \rightarrow \mathrm{NAc}$ shell projection or following reacquisition and repunishment in rats expressing KORD in this projection. Our results demonstrate a critical role of vSub in context-induced relapse after punishment-imposed abstinence and suggest that this effect involves the vSub $\rightarrow$ NAc shell projection during the first relapse episode.

\section{Role of ventral subiculum in context-induced relapse}

Our results demonstrate a critical role of vSub in context-induced relapse to alcohol seeking after punishment-imposed abstinence. These findings extend previous results on the role of vSub (Bossert and Stern, 2014) and the vSub $\rightarrow$ NAc shell projection (Bossert et al., 2015) in context-induced reinstatement of heroin seeking after extinction in which we used a traditional anatomical disconnection procedure (Gold, 1966). There is also evidence for a role of ventral hippocampal areas, located dorsal to vSub, in context-induced reinstatement of cocaine seeking after extinction (Lasseter et al., 2010). 
A

\begin{tabular}{|c|cc|c}
$\begin{array}{c}\text { Home-cage } \\
\text { drinking }\end{array}$ & $\begin{array}{c}\text { Self-administration } \\
\text { training }\end{array}$ & $\begin{array}{c}\text { Punishment } \\
\text { training }\end{array}$ & $\begin{array}{c}\text { Relapse } \\
\text { test }\end{array}$ \\
\hline Virus injections & Context A & Context B & $\begin{array}{c}\text { Context A \& B } \\
\text { Vehicle or Sal B } \\
\text { Systemic injections }\end{array}$
\end{tabular}

B
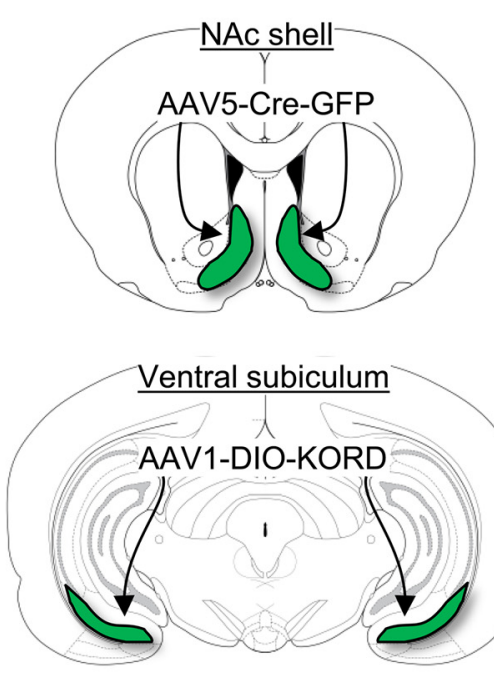

Example virus expression
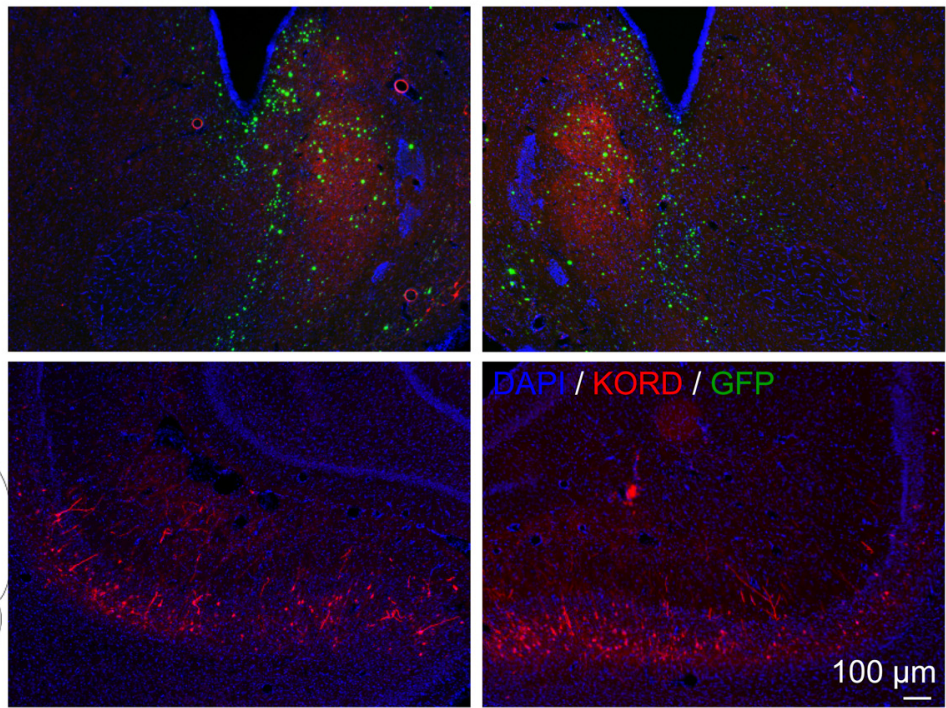

$100 \mu \mathrm{m}$

C
Effect of KORD-mediated inhibition of vSub $\rightarrow$ NAc shell neurons on context- induced relapse to alcohol seeking
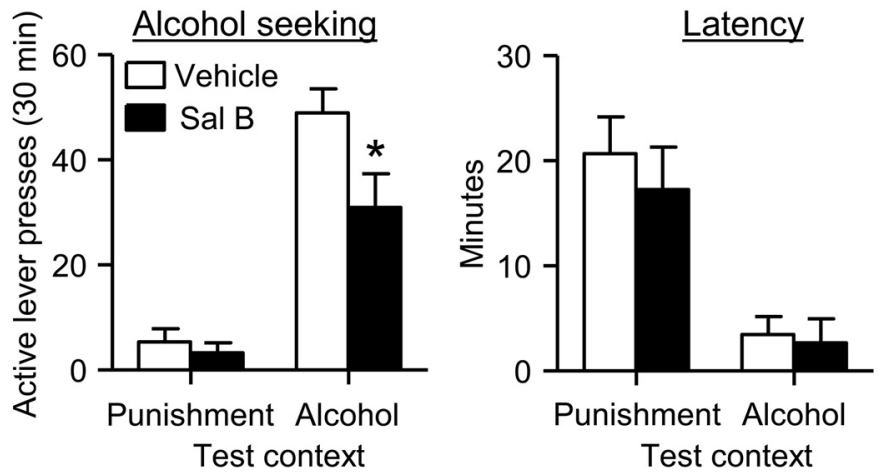

Figure 5. Chemogenetic inhibition of vSub $\rightarrow$ NAc shell projection decreases context-induced relapse of alcohol seeking after punishment-imposed abstinence. $\boldsymbol{A}$, Outline of experimental procedure. $B$, Schematic of AAV5-Cre injections in NAc shell and AAV1-DI0-KORD injections in vSub. C, Data are mean \pm SEM; number of active lever presses (left) and latency to first active lever press (right) during the first relapse test. $n=13-16$ per group. ${ }^{*}$ Different from the Vehicle condition, $p<0.05$

Thus, although a role of vSub in context-induced reinstatement of alcohol seeking after extinction has not been established, a tentative conclusion is that $\mathrm{vSub}$ and $\mathrm{vSub} \rightarrow \mathrm{NAc}$ shell projections are critical for context-induced relapse independent of the self-administered drug and the mechanism used to impose abstinence. Support for this notion comes from the findings that NAc shell is critical for contextinduced reinstatement after extinction across drug classes (Bossert et al., 2007; Fuchs et al., 2008b; Chaudhri et al., 2009) and contextinduced relapse to alcohol seeking after punishment (Marchant and Kaganovsky, 2015).

The vSub and other subregions of the ventral hippocampus have been implicated in other forms of context-dependent learning (Bannerman et al., 2004). For example, excitotoxic lesion or reversible inactivation of ventral hippocampus decreases renewal of conditioned fear (Maren, 1999; Hobin et al., 2006). Thus, one potential account of the present and previous results is that the primary function of ventral hippocampus is to encode the motivational significance of emotionally relevant contexts. However, there are several studies implicating vSub in drug seeking in experiments where the context was not manipulated. For example, electrical stimulation of vSub reinstates cocaine or amphetamine seeking after extinction (Vorel et al., 2001; Taepavarapruk et al., 2015). Inactivation of ventral hippocampus or vSub with muscimol+baclofen or lidocaine decreases cue and drug priming-induced reinstatement of cocaine and methamphetamine seeking (Sun and Rebec, 2003; Hiranita et al., 2006; Rogers and See, 2007). Additionally, inactivation of ventral hippocampus with muscimol+baclofen decreases the effect of repeated restraint stress, given during abstinence, on enhanced reacquisition of nicotine self-administration ( $\mathrm{Yu}$ and Sharp, 2015). These data point to a more general role of vSub in promoting relapse to drug seeking. 

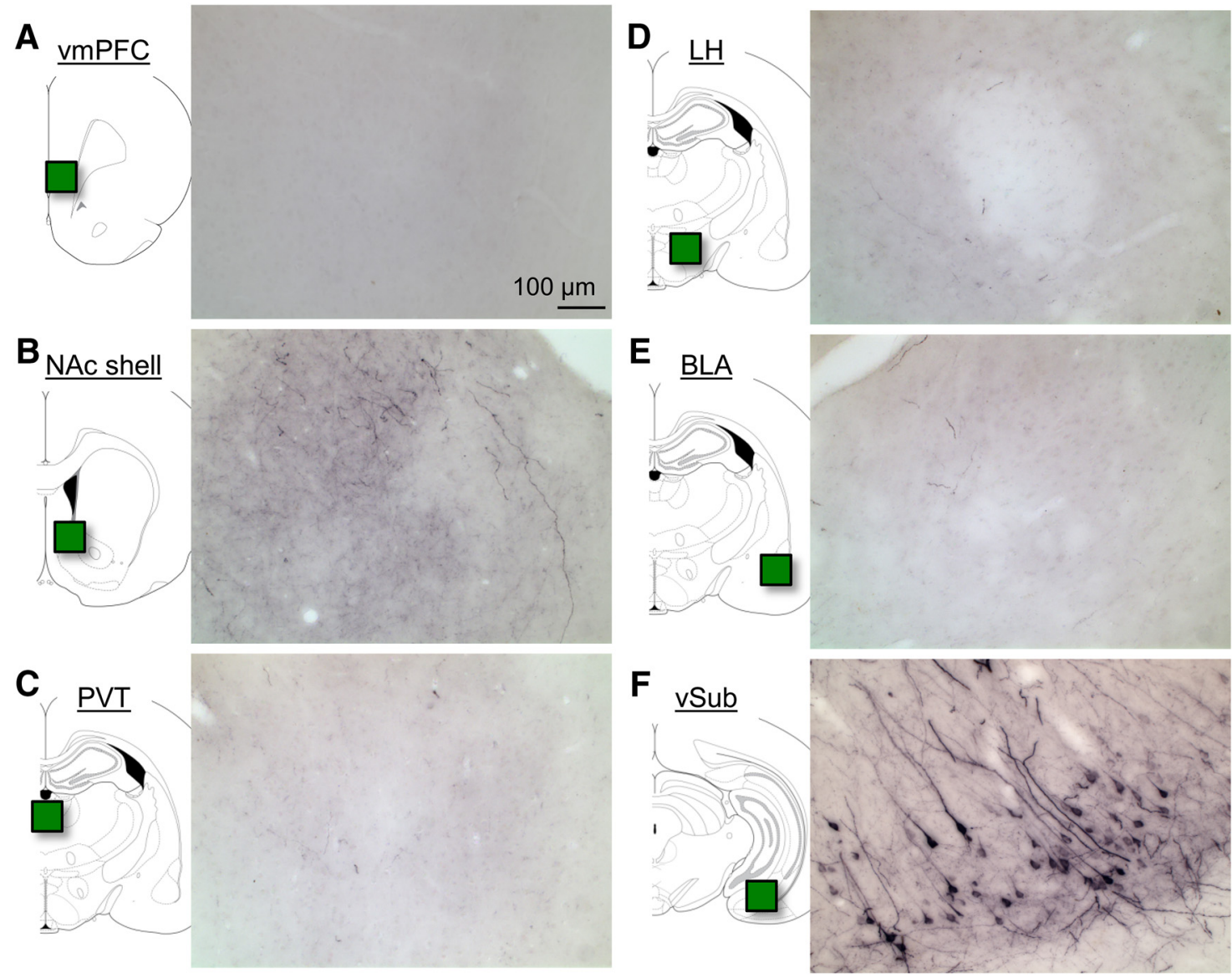

Figure 6. vSub $\rightarrow \mathrm{NAcshell}$ projections do not send collateral projections to other vSub projection areas. Representative photomicrographs of $\mathrm{HA}$ immunoreactivity from a rat in Experiment 3 that received AAV5-Cre in NAc shell and AAV1-DIO-KORD in vSub. A, vmPFC. B, NAc shell. C, PVT. D, Lateral hypothalamus (LH). $\boldsymbol{E}$, BLA. $\boldsymbol{F}$, vSub.

Finally, anatomical and synaptic physiology studies suggest that $\mathrm{vSub} \rightarrow \mathrm{NAc}$ shell projection neurons are glutamatergic (Christie et al., 1987; Britt et al., 2012). There is also evidence that glutamate and dopamine (via D1 receptors) act in synergy to promote activity of NAc neurons (O'Donnell, 2003; Floresco, 2007). Thus, we propose that vSub glutamate release in NAc shell acts in combination with dopamine, originating from the ventral tegmental area (Nauta et al., 1978), to promote context-induced relapse to alcohol seeking. Evidence supporting this idea is that chemical and electrical vSub stimulation increases NAc dopamine release (Legault et al., 2000; Taepavarapruk et al., 2000), an effect that is dependent on both ventral tegmental area activity (Legault et al., 2000) and NAc glutamate receptors (Taepavarapruk et al., 2000; Floresco et al., 2001). Additionally, we recently found that blockade of NAc shell dopamine D1 receptors decreases context-induced relapse to alcohol seeking after punishmentimposed abstinence (Marchant and Kaganovsky, 2015).

\section{Methodological and conceptual considerations}

Several issues should be considered in the interpretation of the present data. One issue is whether our findings from experiments using the genetically selected $\mathrm{P}$ rats generalize to outbred rat strains that consume less alcohol than the P rats. Another issue is that the effects on context-induced relapse of vSub reversible inactivation or chemogenetic inhibition of vSub $\rightarrow$ NAc shell projections are due to nonspecific performance deficits. This is unlikely because we previously found no effect of vSub muscimol+baclofen injections on high-rate operant responding for food (Bossert and Stern, 2014), and SalB had no effect on context-induced relapse in rats expressing hM3D in vSub $\rightarrow$ NAc shell neurons. A second issue is that the lower vSub KORD (HA-IR) expression in the vehicle-injected rats (compared with the SalB-injected rats) contributed to the group differences in context-induced relapse (Fig. $5 C$ ). This is unlikely because the two groups did not differ in their response latency during testing or in other behavioral measures (acquisition and reacquisition of alcohol self-administration, punishment, and repunishment responding (data not shown).

Another issue is the relative contribution of the vSub $\rightarrow \mathrm{NAc}$ projection to the role of vSub in context-induced relapse after punishment. As seen in Figures 3 and 5, we observed a greater reduction of alcohol seeking after vSub inactivation than after chemogenetic inhibition of $\mathrm{vSub} \rightarrow \mathrm{NAc}$ shell projections. A potential interpretation of this difference is that vSub projections to other brain regions also play a role in context-induced relapse. Although this possibility cannot be ruled out, we speculate that the weaker effect of our retro-DREADD manipulation is likely due to the fact that this manipulation only partially inhibited the activity of the projection because not all projection neurons were expressing KORD. We observed approximately half the number of HA-positive neurons in Experiment 3 compared with the number of CTb-positive neurons in Experiment 1. Thus, the observed behavioral effects of SalB may underestimate the contribution of the vSub $\rightarrow$ NAc shell projection to context-induced relapse. In this regard, the serotype of the KORD virus we used in the present study was different from the one we used in our 
previous study (Marchant et al., 2016), resulting in a lower number of KORD-expressing neurons in the present study. Another issue related to the retro-DREADD methodology is that the observed behavioral effects may be due to collateral projections to brain areas other than those injected with the retrograde AAVCre. This possibility is unlikely in our study because very few vSub projection neurons to a given brain area send collaterals to other brain areas (Namura et al., 1994; Naber and Witter, 1998). Indeed, as can be seen in Figure 6, using this dual-virus strategy, we observe HA labeling of terminals in NAc shell but not in other vSub projection areas.

Another issue to consider is that our experimental manipulations (vSub inactivation, chemogenetic inhibition of the vSub $\rightarrow$ NAc shell projection) had no effect on response latency during testing. These results suggest that neuronal activity in vSub and vSub $\rightarrow$ NAc shell projection does not mediate the initial context-driven alcohol seeking but underlies other learning and motivational processes that control drug seeking during the nonreinforced relapse tests.

Finally, an unexpected finding in our study was that chemogenetic inhibition of the vSub $\rightarrow$ NAc shell projections had no effect on context-induced relapse after reacquisition and repunishment. The reasons for this time-limited role of vSub $\rightarrow \mathrm{NAc}$ shell projection in context-induced relapse are unknown and may be due to multiple factors, including the rat strain, the effectiveness of neuronal inhibition by KORD, and other procedural factors. Noteworthy, relevant literature does not exist because, over the last decades, studies using relapse models have not compared mechanisms of initial versus repeated relapse/ reinstatement episodes after reacquisition of drug selfadministration (Venniro et al., 2016). However, for at least one form of relapse, reacquisition after extinction (Millan et al., 2013; McNally, 2014), there is evidence for pharmacological dissociation of reacquisition versus initial acquisition of alcohol self-administration: the former is naloxone-sensitive, whereas the latter is not (Perry and McNally, 2012). Based on these findings, one potential account of our data, which can only be resolved by future studies, is that mechanisms underlying the initial relapse episode might be different from those involved in subsequent relapse episodes.

\section{Concluding remarks}

We used our recently developed model of context-induced relapse where abstinence is voluntary and studied the role of projections to NAc shell in this form of relapse. Our results demonstrate a critical role of vSub in context-induced relapse after punishment-imposed abstinence and further suggest a role of the $\mathrm{vSub} \rightarrow \mathrm{NAc}$ shell projection in this form of relapse. A surprising finding was that chemogenetic inhibition of $\mathrm{vSub} \rightarrow \mathrm{NAc}$ shell projection, which decreased first-episode context-induced relapse, had no effect on relapse after reacquisition of alcohol self-administration and repunishment. This unexpected finding may have implications for future studies on mechanisms of drug relapse in rat models. Over the years, relapse studies in the addiction field have been exclusively limited to the investigation of an initial relapse episode induced by exposure to drug priming, stress, and drug cues or contexts (Kalivas and McFarland, 2003; Bossert et al., 2013; Mantsch et al., 2016; Venniro et al., 2016). Our serendipitous findings on the dissociable effects of SalB injections on the first versus second context-induced relapse episode after reacquisition and repunishment suggest that studies on mechanisms underlying relapse after multiple prior relapse episodes, which commonly occurs in most alcohol and drug users (O'Brien,
1997; Heilig et al., 2011), are warranted. Finally, based on previous studies on the differences in mechanism of drug reward and relapse across drug classes (Badiani et al., 2011; Badiani, 2013), another question for future research is whether the circuit mechanism identified here generalizes to other drugs of abuse.

\section{References}

Armbruster BN, Li X, Pausch MH, Herlitze S, Roth BL (2007) Evolving the lock to fit the key to create a family of $\mathrm{G}$ protein-coupled receptors potently activated by an inert ligand. Proc Natl Acad Sci U S A 104:51635168. CrossRef Medline

Badiani A (2013) Substance-specific environmental influences on drug use and drug preference in animals and humans. Curr Opin Neurobiol 23: 588-596. CrossRef Medline

Badiani A, Belin D, Epstein D, Calu D, Shaham Y (2011) Opiate versus psychostimulant addiction: the differences do matter. Nat Rev Neurosci 12:685-700. CrossRef Medline

Bannerman DM, Rawlins JN, McHugh SB, Deacon RM, Yee BK, Bast T, Zhang WN, Pothuizen HH, Feldon J (2004) Regional dissociations within the hippocampus: memory and anxiety. Neurosci Biobehav Rev 28:273-283. CrossRef Medline

Blume AW, Schmaling KB, Marlatt GA (2006) Recent drinking consequences, motivation to change, and changes in alcohol consumption over a three month period. Addict Behav 31:331-338. CrossRef Medline

Boender AJ, de Jong JW, Boekhoudt L, Luijendijk MC, van der Plasse G, Adan RA (2014) Combined use of the canine adenovirus-2 and DREADD-technology to activate specific neural pathways in vivo. PLoS One 9:e95392. CrossRef Medline

Bossert JM, Stern AL (2014) Role of ventral subiculum in context-induced reinstatement of heroin seeking in rats. Addict Biol 19:338-342. CrossRef Medline

Bossert JM, Gray SM, Lu L, Shaham Y (2006) Activation of group II metabotropic glutamate receptors in the nucleus accumbens shell attenuates context-induced relapse to heroin seeking. Neuropsychopharmacology 31:2197-2209. CrossRef Medline

Bossert JM, Poles GC, Wihbey KA, Koya E, Shaham Y (2007) Differential effects of blockade of dopamine D1-family receptors in nucleus accumbens core or shell on reinstatement of heroin seeking induced by contextual and discrete cues. J Neurosci 27:12655-12663. CrossRef Medline

Bossert JM, Marchant NJ, Calu DJ, Shaham Y (2013) The reinstatement model of drug relapse: recent neurobiological findings, emerging research topics, and translational research. Psychopharmacology 229:453-476. CrossRef Medline

Bossert JM, Adhikary S, St Laurent R, Marchant NJ, Wang HL, Morales M, Shaham Y (2015) Role of projections from ventral subiculum to nucleus accumbens shell in context-induced reinstatement of heroin seeking in rats. Psychopharmacology Advance online publication. Retrieved Sep. 7, 2015. CrossRef Medline

Bouton ME, Bolles RC (1979) Role of conditioned contextual stimuli in reinstatement of extinguished fear. J Exp Psychol Anim Behav Process 5:368-378. CrossRef Medline

Bouton ME, Schepers ST (2015) Renewal after the punishment of free operant behavior. J Exp Psychol Anim Learn Cogn 41:81-90. CrossRef Medline

Britt JP, Benaliouad F, McDevitt RA, Stuber GD, Wise RA, Bonci A (2012) Synaptic and behavioral profile of multiple glutamatergic inputs to the nucleus accumbens. Neuron 76:790-803. CrossRef Medline

Chaudhri N, Sahuque LL, Janak PH (2009) Ethanol seeking triggered by environmental context is attenuated by blocking dopamine D1 receptors in the nucleus accumbens core and shell in rats. Psychopharmacology 207:303-314. CrossRef Medline

Christie MJ, Summers RJ, Stephenson JA, Cook CJ, Beart PM (1987) Excitatory amino acid projections to the nucleus accumbens septi in the rat: a retrograde transport study utilizingd $\left[{ }^{3} \mathrm{H}\right]$ aspartate and $\left[{ }^{3} \mathrm{H}\right] \mathrm{GABA}$. Neuroscience 22:425-439. CrossRef Medline

Collins BN, Brandon TH (2002) Effects of extinction context and retrieval cues on alcohol cue reactivity among nonalcoholic drinkers. J Consult Clin Psychol 70:390-397. CrossRef Medline

Crombag HS, Shaham Y (2002) Renewal of drug seeking by contextual cues after prolonged extinction in rats. Behav Neurosci 116:169-173. CrossRef Medline 
Dougherty KA, Islam T, Johnston D (2012) Intrinsic excitability of CA1 pyramidal neurones from the rat dorsal and ventral hippocampus. J Physiol 590:5707-5722. CrossRef Medline

Epstein DH, Preston KL (2003) The reinstatement model and relapse prevention: a clinical perspective. Psychopharmacology 168:31-41. CrossRef Medline

Floresco SB (2007) Dopaminergic regulation of limbic-striatal interplay. J Psychiatry Neurosci 32:400-411. Medline

Floresco SB, Todd CL, Grace AA (2001) Glutamatergic afferents from the hippocampus to the nucleus accumbens regulate activity of ventral tegmental area dopamine neurons. J Neurosci 21:4915-4922. Medline

Fuchs RA, Evans KA, Ledford CC, Parker MP, Case JM, Mehta RH, See RE (2005) The role of the dorsomedial prefrontal cortex, basolateral amygdala, and dorsal hippocampus in contextual reinstatement of cocaine seeking in rats. Neuropsychopharmacology 30:296-309. CrossRef Medline

Fuchs RA, Lasseter HC, Ramirez DR, Xie X (2008a) Relapse to drug seeking following prolonged abstinence: the role of environmental stimuli. Drug Discov Today Dis Models 5:251-258. CrossRef Medline

Fuchs RA, Ramirez DR, Bell GH (2008b) Nucleus accumbens shell and core involvement in drug context-induced reinstatement of cocaine seeking in rats. Psychopharmacology 200:545-556. CrossRef Medline

Girault JA, Valjent E, Caboche J, Hervé D (2007) ERK2: a logical AND gate critical for drug-induced plasticity? Curr Opin Pharmacol 7:77-85. CrossRef Medline

Gold RM (1966) Aphagia and adipsia produced by unilateral hypothalamic lesions in rats. Am J Physiol 211:1274-1276. Medline

Hamlin AS, Newby J, McNally GP (2007) The neural correlates and role of D1 dopamine receptors in renewal of extinguished alcohol-seeking. Neuroscience 146:525-536. CrossRef Medline

Hamlin AS, Clemens KJ, Choi EA, McNally GP (2009) Paraventricular thalamus mediates context-induced reinstatement (renewal) of extinguished reward seeking. Eur J Neurosci 29:802-812. CrossRef Medline

Harnett MT, Makara JK, Spruston N, Kath WL, Magee JC (2012) Synaptic amplification by dendritic spines enhances input cooperativity. Nature 491:599-602. CrossRef Medline

Heilig M, Goldman D, Berrettini W, O’Brien CP (2011) Pharmacogenetic approaches to the treatment of alcohol addiction. Nat Rev Neurosci 12: 670-684. CrossRef Medline

Hiranita T, Nawata Y, Sakimura K, Anggadiredja K, Yamamoto T (2006) Suppression of methamphetamine-seeking behavior by nicotinic agonists. Proc Natl Acad Sci U S A 103:8523-8527. CrossRef Medline

Hobin JA, Ji J, Maren S (2006) Ventral hippocampal muscimol disrupts context-specific fear memory retrieval after extinction in rats. Hippocampus 16:174-182. CrossRef Medline

Kalivas PW, McFarland K (2003) Brain circuitry and the reinstatement of cocaine-seeking behavior. Psychopharmacology 168:44-56. CrossRef Medline

Klingemann HK (1991) The motivation for change from problem alcohol and heroin use. Br J Addict 86:727-744. CrossRef Medline

Lasseter HC, Xie X, Ramirez DR, Fuchs RA (2010) Sub-region specific contribution of the ventral hippocampus to drug context-induced reinstatement of cocaine-seeking behavior in rats. Neuroscience 171:830-839. CrossRef Medline

Legault M, Rompré PP, Wise RA (2000) Chemical stimulation of the ventral hippocampus elevates nucleus accumbens dopamine by activating dopaminergic neurons of the ventral tegmental area. J Neurosci 20:1635-1642. Medline

Mantsch JR, Baker DA, Funk D, Lê AD, Shaham Y (2016) Stress-induced reinstatement of drug seeking: 20 years of progress. Neuropsychopharmacology 41:335-356. CrossRef Medline

Marchant NJ, Kaganovsky K (2015) A critical role of nucleus accumbens dopamine D1-family receptors in renewal of alcohol seeking after punishment-imposed abstinence. Behav Neurosci 129:281-291. CrossRef Medline

Marchant NJ, Hamlin AS, McNally GP (2009) Lateral hypothalamus is required for context-induced reinstatement of extinguished reward seeking. J Neurosci 29:1331-1342. CrossRef Medline

Marchant NJ, Khuc TN, Pickens CL, Bonci A, Shaham Y (2013) Contextinduced relapse to alcohol seeking after punishment in a rat model. Biol Psychiatry 73:256-262. CrossRef Medline

Marchant NJ, Rabei R, Kaganovsky K, Caprioli D, Bossert JM, Bonci A, Sha- ham Y (2014) A critical role of lateral hypothalamus in context-induced relapse to alcohol seeking after punishment-imposed abstinence. J Neurosci 34:7447-7457. CrossRef Medline

Marchant NJ, Kaganovsky K, Shaham Y, Bossert JM (2015) Role of corticostriatal circuits in context-induced reinstatement of drug seeking. Brain Res 1628:219-232. CrossRef Medline

Marchant NJ, Whitaker LR, Bossert JM, Harvey BK, Hope BT, Kaganovsky K, Adhikary S, Prisinzano TE, Vardy E, Roth BL, Shaham Y (2016) Behavioral and physiological effects of a novel kappa-opioid receptor-based DREADD in rats. Neuropsychopharmacology 41:402-409. CrossRef Medline

Maren S (1999) Neurotoxic or electrolytic lesions of the ventral subiculum produce deficits in the acquisition and expression of Pavlovian fear conditioning in rats. Behav Neurosci 113:283-290. CrossRef Medline

Marinelli PW, Funk D, Juzytsch W, Lê AD (2010) Opioid receptors in the basolateral amygdala but not dorsal hippocampus mediate context-induced alcohol seeking. Behav Brain Res 211:58-63. CrossRef Medline

McFarland K, Kalivas PW (2001) The circuitry mediating cocaine-induced reinstatement of drug-seeking behavior. J Neurosci 21:8655-8663. Medline

McNally GP (2014) Extinction of drug seeking: neural circuits and approaches to augmentation. Neuropharmacology 76:528-532. CrossRef Medline

Millan EZ, McNally GP (2011) Accumbens shell AMPA receptors mediate expression of extinguished reward seeking through interactions with basolateral amygdala. Learn Mem 18:414-421. CrossRef Medline

Millan EZ, Milligan-Saville J, McNally GP (2013) Memory retrieval, extinction, and reinstatement of alcohol seeking. Neurobiol Learn Mem 101: 26-32. CrossRef Medline

Morgan JI, Curran T (1991) Stimulus-transcription coupling in the nervous system: involvement of the inducible proto-oncogenes fos and jun. Annu Rev Neurosci 14:421-451. CrossRef Medline

Naber PA, Witter MP (1998) Subicular efferents are organized mostly as parallel projections: a double-labeling, retrograde-tracing study in the rat. J Comp Neurol 393:284-297. CrossRef Medline

Nair SG, Strand NS, Neumaier JF (2013) DREADDing the lateral habenula: a review of methodological approaches for studying lateral habenula function. Brain Res 1511:93-101. CrossRef Medline

Namura S, Takada M, Kikuchi H, Mizuno N (1994) Topographical organization of subicular neurons projecting to subcortical regions. Brain Res Bull 35:221-231. CrossRef Medline

Nauta WJ, Smith GP, Faull RL, Domesick VB (1978) Efferent connections and nigral afferents of the nucleus accumbens septi in the rat. Neuroscience 3:385-401. CrossRef Medline

O’Brien CP (1997) A range of research-based pharmacotherapies for addiction. Science 278:66-70. CrossRef Medline

O'Donnell P (2003) Dopamine gating of forebrain neural ensembles. Eur J Neurosci 17:429-435. CrossRef Medline

Perry CJ, McNally GP (2012) Naloxone prevents the rapid reacquisition but not acquisition of alcohol seeking. Behav Neurosci 126:599-604. CrossRef Medline

Rogers JL, See RE (2007) Selective inactivation of the ventral hippocampus attenuates cue-induced and cocaine-primed reinstatement of drug-seeking in rats. Neurobiol Learn Mem 87:688-692. CrossRef Medline

Simms JA, Steensland P, Medina B, Abernathy KE, Chandler LJ, Wise R, Bartlett SE (2008) Intermittent access to $20 \%$ ethanol induces high ethanol consumption in Long-Evans and Wistar rats. Alcohol Clin Exp Res 32:1816-1823. CrossRef Medline

Sun W, Rebec GV (2003) Lidocaine inactivation of ventral subiculum attenuates cocaine-seeking behavior in rats. J Neurosci 23:10258-10264. Medline

Taepavarapruk P, Floresco SB, Phillips AG (2000) Hyperlocomotion and increased dopamine efflux in the rat nucleus accumbens evoked by electrical stimulation of the ventral subiculum: role of ionotropic glutamate and dopamine D1 receptors. Psychopharmacology 151:242-251. CrossRef Medline

Taepavarapruk P, Butts KA, Phillips AG (2015) Dopamine and glutamate interaction mediates reinstatement of drug-seeking behavior by stimula- 
tion of the ventral subiculum. Int J Neuropsychopharmacol 18:piipyu008. CrossRef Medline

Vardy E, Robinson JE, Li C, Olsen RH, DiBerto JF, Giguere PM, Sassano FM, Huang XP, Zhu H, Urban DJ, White KL, Rittiner JE, Crowley NA, Pleil KE, Mazzone CM, Mosier PD, Song J, Kash TL, Malanga CJ, Krashes MJ, et al. (2015) A new DREADD facilitates the multiplexed chemogenetic interrogation of behavior. Neuron 86:936-946. CrossRef Medline

Venniro M, Caprioli D, Shaham Y (2016) Animal models of drug relapse and craving: from drug priming-induced reinstatement to incubation of craving after voluntary abstinence. Prog Brain Res 224:25-52. CrossRef Medline

Voorn P, Vanderschuren LJ, Groenewegen HJ, Robbins TW, Pennartz CM (2004) Putting a spin on the dorsal-ventral divide of the striatum. Trends Neurosci 27:468-474. CrossRef Medline

Vorel SR, Liu X, Hayes RJ, Spector JA, Gardner EL (2001) Relapse to cocaine-seeking after hippocampal theta burst stimulation. Science 292: 1175-1178. CrossRef Medline

Wikler A (1973) Dynamics of drug dependence. Implications of a conditioning theory for research and treatment. Arch Gen Psychiatry 28:611616. CrossRef Medline

Wise RA (1973) Voluntary ethanol intake in rats following exposure to ethanol on various schedules. Psychopharmacology 29:203-210. CrossRef Medline

Xie X, Lasseter HC, Ramirez DR, Ponds KL, Wells AM, Fuchs RA (2012) Subregion-specific role of glutamate receptors in the nucleus accumbens on drug context-induced reinstatement of cocaine-seeking behavior in rats. Addict Biol 17:287-299. CrossRef Medline

Yu G, Sharp BM (2015) Basolateral amygdala and ventral hippocampus in stress-induced amplification of nicotine self-administration during reacquisition in rat. Psychopharmacology 232:2741-2749. CrossRef Medline 